\title{
Mineralogical and isotopic record of biotic and abiotic diagenesis of the Callovian-Oxfordian clayey formation of Bure (France).
}

Lerouge C. ${ }^{a^{*}}$, Grangeon S. ${ }^{b}$, Gaucher E.C. ${ }^{a}$, Tournassat C. ${ }^{a}$, Agrinier P. ${ }^{c}$, Guerrot C. ${ }^{a}$, Widory D. ${ }^{a}$, Fléhoc C. ${ }^{a}$, Ramboz C. ${ }^{d}$, Vinsot A. ${ }^{e}$, Buschaert $S .^{b}$

a BRGM, BP36009, 45060 Orléans cédex 2, France

${ }^{b}$ ANDRA, 1-7 rue Jean-Monnet, 92298 Châtenay-Malabry cedex, France

${ }^{c}$ Laboratoire de Géochimie des Isotopes stables, IPGP, Place Jussieu, case 89, 75252 Paris cedex 05

${ }^{d}$ Institut des Sciences de la Terre d'Orléans (ISTO) - CNRS, 1 A rue de la Ferollerie, 45071 ORLEANS Cedex 2, France

${ }^{e}$ ANDRA, Meuse/Haute-Marne Underground research Laboratory (URL), RD 960, 55290 Bure, France

* Corresponding author.

E-mail address: c.lerouge@brgm.fr (C. Lerouge)

\section{Abstract}

The Callovian-Oxfordian (COx) clayey unit is being studied in the Eastern part of the Paris Basin at depths between 400 and $500 \mathrm{~m}$ depth to assess of its suitability for nuclear waste disposal. The present study combines new mineralogical and isotopic data to describe the sedimentary history of the COx unit. Petrologic study provided evidence of the following diagenetic mineral sequence: 1) framboidal pyrite and micritic calcite, 2) iron-rich euhedral carbonates (ankerite, sideroplesite) and glauconite 3) limpid calcite and dolomite and celestite infilling residual porosity in bioclasts and cracks, 4) chalcedony 5) quartz/calcite. Pyrite in bioturbations shows a wide range of $\delta^{34} S$ (-38 to $+34.5 \%$ ), providing evidence of bacterial sulphate reduction processes in changing sedimentation conditions. The most negative values ( -38 to $-22 \%$ ), measured in the lower part of the COx unit indicate precipitation of pyrite in a marine environment with a continuous sulphate supply. The most positive pyrite $\delta^{34} S$ values $(-14$ up to $+34.5 \%$ ) in the upper part of the COx unit indicate pyrite precipitation in a closed system. Celestite $\delta^{34} S$ values reflect the last evolutionary stage of the system when bacterial activity ended; however its deposition cannot be possible without sulphate supply due to carbonate bioclast dissolution. The ${ }^{87} \mathrm{Sr} /{ }^{86} \mathrm{Sr}$ ratio of celestite $(0.706872-0.707040)$ is consistent with deposition from Jurassic marine-derived waters. Carbon and oxygen isotopic compositions of bulk calcite and dolomite are consistent with marine carbonates. Siderite, only 
present in the maximum clay zone, has chemical composition and $\delta^{18} \mathrm{O}$ consistent with a marine environment. Its $\delta^{13} \mathrm{C}$ is however lower than those of marine carbonates, suggesting a contribution of ${ }^{13} \mathrm{C}$-depleted carbon from degradation of organic matter. $\delta^{18} \mathrm{O}$ values of diagenetic chalcedony range between +27 and $+31 \%$, suggesting precipitation from marine-derived pore waters. Late calcite crosscutting a vein filled with chalcedony and celestite, and late euhedral quartz in a limestone from the top of the formation have lower $\delta^{18} \mathrm{O}$ values $(\sim+19 \%)$, suggesting that they precipitated from meteoric fluids, isotopically close to present-day pore waters of the formation. Finally, the study illustrates the transition from very active, biotic diagenesis to abiotic diagenesis. This transition appears to be driven by compaction of the sediment, which inhibited movement of bacterial cells by reduction of porosity and pore sizes, rather than a lack of inorganic carbon or sulfates.

Keywords: clay formation, diagenesis, stable isotopes, Bure URL, ANDRA. 


\section{Introduction}

Diagenesis of sedimentary rock is an important area of research both in academic and applied studies. Its applications include extraction of metals, coal, oil, and gas (Veizer and Mackenzie, 2004), as well as projects investigating options for deep nuclear waste long-term storage. The diagenesis of formations being considered as host rocks for waste disposal is important in understanding present-day pore water chemistry and the transport behaviour of solutes which in turn, is crucial to the determination of the durability of the materials used for repository construction and waste packaging and the conditions under which radionuclides may be transported in the host formation. Data to access these issues are thus needed to support safety analysis of the disposal scheme being proposed.

Since 2004, ANDRA (The National Radioactive Waste Management Agency of France) has been developing an Underground Research Laboratory (URL) at Bure, in the Eastern part of the Paris Basin, to study the feasibility of nuclear waste disposal in a deep, thick, Callovian-Oxfordian clayrich formation (hereafter abbreviated COx). The target formation lies between the Dogger overlaid limestone and the Oxfordian overlying limestone, and is accessible at 400 meters depth in the URL (Gaucher et al., 2004; Delay, 2007; Clauer et al., 2007). Since 1994, numerous studies have been conducted to determine mineral stabilities and present-day porewater chemistry (Gaucher et al., 2006, 2009) and transport mechanisms of solutes within the COx unit and between the COx unit and adjacent carbonate aquifers (Buschaert et al., 2007). Solute transport and diffusion mechanisms are illustrated by past water/rock interactions and by physico-chemical processes associated with sedimentation and diagenesis. The latter include processes such as compaction, burial, dissolution, and cementation that generated the present-day petrophysical properties of the claystones.

Present-day pore waters have been analysed for chemistry and isotopes (Gaucher et al, 2006, 2009, Giannesini, 2006; Vinsot et al., 2008). Understanding of solute transport has benefited from texture, porosity, permeability, and diffusion measurements (Gaucher et al., 2004; Yven et al., 2007; Delay et al., 2007; Decostes et al, 2008) and from experimental measurements (ANDRA, 2005; Appelo et al., 2008). The oxygen, hydrogen and strontium isotopic compositions of present-day pore waters in the COx and adjacent units show a meteoric signature (Giannesini, 2006). Contrastingly, carbon, oxygen, and strontium isotope studies on carbonate (Ader and Javoy, 1998; Casanova et al., 1999; Buschaert et al., 2004; Lerouge et al., 2010a), suggest that virtually all diagenetic phases were precipitated from marine-derived waters. In Mesozoic limestones adjacent to the COx unit, carbon, oxygen, and strontium isotopes show that the late diagenetic calcites in vugs and fractures were precipitated from meteoric waters (Casanova et al., 2001; Vincent et al., 2001; Buschaert et al., 2004; Brigaud et al., 2010). 
The purpose of the present work was to establish the mineral sequence of the COx clay formation, to determine the stability of the diagenetic phases and to delineate the evolution of pore waters through geological time. Particular emphasis was placed on describing diagenetic phases including pyrite, celestite, carbonates and chalcedony, on the processes involved in their deposition and on the effects of these processes on redox conditions and phase stabilities. This was supported by petrological work on (i) detrital phases, including their chemistry and stability, in order to determine their role in the precipitation of the late diagenetic phases, and (ii) mineral textures particularly of diagenetic phases to clarify their sequence of precipitation and their stability during basin evolution. Oxygen, sulphur and strontium isotopes of sulphates and sulphides, oxygen and carbon isotopes of the late carbonate phases and oxygen of chalcedony were measured and interpreted to define deposition processes, and fluid sources along geological time. 


\section{Geological setting}

The Underground Research Laboratory is located at Bure in the eastern part of the Paris Basin. The lithostratigraphic log of the whole sequence, sedimentation conditions of the Dogger to the Kimmeridgian sequence and the tectonic setting in the studied area (URL and surrounding area), are available in ANDRA $(2001,2005)$. Mineralogy and geochemistry of the COx rocks have been extensively documented (e.g. Gaucher et al., 2004, ANDRA, 2005) and Clauer et al. (2007). Main informations are summarized below.

\section{Lithostratigraphic sequence - sedimentation conditions}

Sedimentation of the Dogger to Kimmeridgian sequence occurred in a quiet marine environment (ANDRA, 2001, 2005). Close to the URL site, the Dogger unit mainly consists of $230 \mathrm{~m}$-thick limestone of shallow-platform, with local emersion episodes (Vincent, 2001; Carpentier, 2004). The overlying Callovian-Oxfordian unit (so-called C2) consists of $130 \mathrm{~m}$-thick fine-grained siliciclastic sediments with a dominant clay component, and represents a deepening of the carbonate plateform (Figure 1). The boundary between Dogger and COx units is marked by one or several sedimentation gaps. The sedimentation change to the Oxfordian corresponds to an evolution towards a new shallow carbonate platform with local emersions and important reef constructions (Vincent, 2001; Carpentier, 2004). The carbonate platform consists of $290 \mathrm{~m}$-thick limestones (oolitic shelf limestone, bioherms and microorganisms-rich limestone). Overlying Kimmeridgian 110 m-thick sediments correspond to three carbonate-claystone units that mark another deepening of the platform.

\section{Tectonic setting}

The eastern Paris basin evolved in an extensional tectonic regime during the Lower and Middle Jurassic, without any significant structural features during the COx sedimentation (Guillocheau et al., 2000). Tectonic episodes were recorded at the base of the Cretaceous and during Aptian. The major extensional phase occurred during Oligocene, producing vertical movements superimposed on earlier vertical and lateral movements of pre-existing faults (Guillocheau et al., 2000; Bergerat et al., 2006). Nowadays the COx unit in the studied area slightly dips at $1-2^{\circ}$ to the west within a monocline due to subsidence at the centre of the basin. The URL site is bounded by major regional fault zones of the Pyrenean and Alpine cycles namely the Vittel fault to the south, the N035 Gondrecourt graben to the east and the NNW-SSE subvertical Marne fault to the west. Geophysical monitoring indicate low seismicity and only slight vertical movements suggesting minimal tectonic activity in the area. 
Organic matter study, fluid inclusion microthermometry and the thermal stability of clay indicated that COx unit has not undergone significant thermicity along geological times, paleotemperature never exceeding $50^{\circ} \mathrm{C}$ (Pellenard et al., 1999; Buschaert et al., 2004; Elion et al., 2005; Clauer et al., 2007). This maximum temperature was reached at the end of Cretaceous sedimentation (Guillocheau et al., 2000; Vincent et al., 2007).

\section{Petrography - Previous works}

Sediments of the COx unit consist of a dominant clay fraction associated with carbonate, quartz with minor feldspars (K-feldspar and albite) (Figure 1b). Evolution of clay fraction proportions are correlated with three transgression/regression cycles identified along long distances on the basis of some well-known carbonate reference levels (Rousset and Clauer, 2003; Clauer et al., 2007). A decimetre-thick unit of bentonite was also described at a depth of $351 \mathrm{~m}$ in the borehole HTM102 (Pellenard et al., 1999), then identified later in boreholes EST103/104 and EST205 (Pellenard and Deconinck, 2006).

Two major groups of rocks were distinguished on the basis of the clay content (Rousset and Clauer, 2003; Yven et al., 2007). The first group is essentially observed at the top of the COx unit (corresponding to C2c and C2d sub-units) between 417 and $445 \mathrm{~m}$ depth in the URL site, and consists of carbonate siltite and silty limestones with alternating hemipelagic clays and detrital materials. The second group is observed between $\sim 445$ and $545 \mathrm{~m}$ at the bottom of the COx unit (corresponding to $\mathrm{C} 2 \mathrm{a}$ and $\mathrm{C} 2 \mathrm{~b}$ sub-units) and consists of silt carbonate claystone with alternating decimetre-thick layers of bioclastic limestone at $517 \mathrm{~m}$ depth. The maximum clay zone (MCZ) defined at 486-489 m depth in borehole EST205 (sub-unit C2b) corresponds to the maximum depth of water attained during the major cycle of sea-level variations in the basin. Beneath and within the MCZ, clay fraction is high (40-60\%) and clay minerals consist of illite, ordered illite/smectite mixedlayers with dominant illite, kaolinite, chlorite and minor biotite (Pellenard et al., 1999; Mosser-Ruck et al., 1999; Rousset and Clauer, 2003; Blanc and Gaucher, 2003; Gaucher et al., 2004; Pellenard and Deconinck, 2006; Yven et al., 2007). Chlorite is tri-octahedral, iron-rich and of chamosite-type, according to the Hey classification (Gaucher et al., 2004). Above the MCZ, the clay fraction decreases towards the top in favour of a silty then of a calcareous-rich fraction (Gaucher et al., 2004; ANDRA, 2005). Kaolinite and biotite disappear, and the ordered illite/smectite mixed-layers are replaced by disordered illite/smectite mixed-layers dominated by smectite. The change of clay minerals is attributed to a change in the sources of terrigenous material related to the paleogeographic and geodynamic evolution of the basin rather than to burial diagenesis (Landais and Elie, 1999; Pellenard et al., 1999; Rousset and Clauer, 2003; ANDRA, 2005; Clauer et al., 2006). Several studies of the COx clay fraction using various analytical approaches provided evidence for very discrete diagenetic clay phases (Mosser-Ruck et al., 1999; Claret et al., 2004; Clauer et al., 2007). 
Carbonates are composed of an important detrital bioclastic fraction (Vaslet et al., 1995; Le Nindre et al., 1995) and of diagenetic carbonates (Gaucher et al., 2004; Tournassat et al., 2008). The carbonate bioclastic fraction studied in the drillholes MSE101, HTM102 and EST103 locally represents up to 30-40 \% of the claystone (Vaslet et al., 1995; Le Nindre et al., 1995; Ferry et al., 2007). It is composed of fauna from different levels of the benthos and from the dismantling of the carbonate platforms, the amounts depending on the sedimentation conditions. Prevailing fossils are bivalves from the upper part of the benthos, but pelagic bivalves (posidonomya), sponges, foraminifers, brachiopods and echinoderms from the deep benthos are also present. Previous observations of carbonate bioclasts were performed in the framework of the study of iodine in carbonates (Claret et al., 2010; Lerouge et al., 2010b). The diagenetic carbonates are virtually all micritic calcite forming the cement of the rock but minor $10 \mu \mathrm{m}$-sized euhedral calcite and dolomite grains are also dispersed in the sediment (Buschaert et al., 2004; Gaucher et al., 2004; Clauer et al., 2007). The dolomite content ranges between 2 and $9 \%$, independently of the whole carbonate content of the rock (Pearson correlation coefficient $=-0.01$, p-value $=0.97$, data after Gaucher et al., 2004).

Accessory diagenetic minerals are pyrite, sphalerite, celestite, siderite, glauconite, and silica (Gaucher et al., 2004). Their contents rarely exceed 1-2 \%. Accessory detrital minerals are chalcopyrite, rutile and titano-magnetite. Detrital organic matter in claystone samples do not exceed 1.4 w\% (Disnar et al., 1996; Cassagnabère, 2001; Claret et al., 2004; Gaucher et al., 2004). Chemical studies showed that terrestrial organic matter is ubiquitous in the clay formation, whereas marine-derived organic matter is mostly observed at the Callovian-Oxfordian transition corresponding to the MCZ (Fauconnier, 1995; Disnar et al., 1996; Michels, 2001; Hautevelle et al., 2007).

Very few tectonic features were described in the COx unit, in contrast to the surrounding limestones in which joints, tensional cracks, styloliths and microfaults are numerous (ANDRA, 2005).

\section{Isotopic geochemistry - Previous works}

The oxygen and carbon isotopic compositions of micritic cement in the COx unit are those expected for marine calcite or sometime slightly depleted in ${ }^{18} \mathrm{O}\left(\delta^{13} \mathrm{C} \sim+0.5\right.$ to $+2.0 \%$ PDB and $\delta^{18} \mathrm{O} \sim+26.2$ to $+28.3 \%$ SMOW) (Buschaert et al., 2004). Only two objects in the Oxfordian part of the COx unit, a tiny fracture (sample HTM2343/356.2 $\mathrm{m}$ ) and small bioclasts filled with calcite (HTM854/371 m), exhibit $\delta^{18} \mathrm{O} \sim 20.9$ to $+23.7 \%$ SMOW, indicating a meteoric component with a $\delta^{18} \mathrm{O}$ ranging between -6.8 to $-2.5 \%$ for temperatures of $32-42^{\circ} \mathrm{C}$ (Buschaert et al., 2004).

The present-day pore waters in the COx unit have a $\delta^{18} \mathrm{O}(-7$ and $-4 \%$ SMOW $)$ indicating a meteoric origin (Girard et al., 2005; Giannesini, 2006) which is distinct from those of adjacent limestones (Buschaert et al., 2007). 
The strontium isotopic composition of calcite and other carbonates (dolomite, siderite) was measured in samples from the COx unit using a sequential extraction procedure avoiding any contamination from strontium adsorbed on clay minerals (Lerouge et al., 2010). The strontium of the exchangeable fraction separated using cobalt hexamine trichloride extraction has a relative homogeneous ${ }^{87} \mathrm{Sr} /{ }^{86} \mathrm{Sr}$ ratio ranging between 0.7073 and 0.7075 . Its similarity with present-day porewaters (0.7074-07076; Vinsot et al., 2008) indicates equilibrium between exchangeable strontium absorbed on clay minerals and present-day waters. The ${ }^{87} \mathrm{Sr} /{ }^{86} \mathrm{Sr}$ ratio of the calcite fraction extracted by $\mathrm{Na}$ acetate buffered with acetic acid at $\mathrm{pH} 5$ ranges between 0.706936 $0.707163(0.706930-0.707148$ with correction age at $160 \mathrm{Ma})$. This fraction corresponds to micritic calcite, euhedral calcite and calcium carbonate polymorphs from the bioclasts of the CallovianOxfordian benthic microfauna. Its strontium signature has a range of values consistent with Callovian-Oxfordian seawater (0.7068-0.7072; Jones et al., 1994), i.e. the age of sedimentation and burial. The ${ }^{87} \mathrm{Sr} /{ }^{86} \mathrm{Sr}$ ratio of other carbonates (dolomite and siderite) extracted by EDTA (0.7068330.707135 ) are also consistent with pristine Callovian-Oxfordian seawater. The small detrital fraction (K-micas and feldspars) shows high strontium isotope values, in agreement with their Hercynian continental origin, providing evidence of low exchange with other main strontium fractions. The ${ }^{87} \mathrm{Sr} /{ }^{86} \mathrm{Sr}$ ratios of celestite provide evidence of two generations. A first generation (EST05433, Bure 1, Bure 2, EST20714: ${ }^{87} \mathrm{Sr} /{ }^{86} \mathrm{Sr}$ ratios 0.7069-0.7070) directly precipitated from the CallovianOxfordian porewaters or remobilizing the $\mathrm{Sr}$ released by the recrystallization of the primary carbonate bioclasts, and consequently recorded chemical conditions of sedimentation and early diagenesis. A later generation of celestite infillings (sample EST05485) exhibits an ${ }^{87} \mathrm{Sr} /{ }^{86} \mathrm{Sr}$ ratio $(0.707373)$ close to present-day pore waters and is clearly in equilibrium with the exchangeable ions and with present-day porewaters. 


\section{Material}

Twenty-five core samples representative of the COx unit were selected at different depths of seven boreholes (EST205, EST212, EST423, PAC1001, PAC1002, PAC2001, PAC2002) from different ANDRA drilling campaigns (Figure 1a). Samples were stored in aluminium bags under vacuum or under nitrogen gas just after drilling. Samples location is plotted in a stratigraphic log along with the mineralogy of EST205 borehole (Gaucher et al., 2004 - Figure 1b).

Among these 25 core samples, two are carbonate-rich claystone (EST12436, EST20714) of the C2b sub-unit, and five are limestone (EST5433, EST20433, EST5485, EST21400, K108) of the C2c and C2d sub-units. Others are claystone of the C2b and C2c sub-units, containing bioturbations filled with pyrite. 3 clay-rich samples of the sub-unit $\mathrm{C} 2 \mathrm{~b}$ contain $\mathrm{cm}$-sized pyritous ammonite (EST25380, EST5738, EST26479), one clay-rich sample of the C2b sub-unit contains a mm-sized tooth fossil (EST5724). Sample EST12536, from a decimetre-thick layer of bioclastic carbonate-rich claystone at the bottom of the $\mathrm{C} 2 \mathrm{~b}$ sub-unit, contains $\mathrm{cm}$-sized specimens of brachiopods and pyrite layers. Cracks crosscutting the rock bedding and attributed to compaction were only observed in two samples (EST20714, EST05485). Core sample EST20714 is a carbonate-rich claystone (subunit C2b) crosscut by a cm-thick crack mainly filled by celestite. Core sample EST5485 (sub-unit $\mathrm{C} 2 \mathrm{c}$ ) is a limestone containing $5 \mathrm{~mm}$-thick cracks filled with celestite, chalcedony and carbonate. Among the twenty five selected samples no tectonic feature was identified.

Eight other rock samples, collected from the excavation of the main gallery were selected for their exceptional mineralogy, texture and fossil contents (samples Bure 1 to Bure 8). They were stored without any peculiar caution. Bure 1 to 6 are carbonate-rich samples. Bure 1, 2 and 3 contain shells of bivalve (up to $4-5 \mathrm{~cm}$ in size) filled with celestite and chalcedony. Bure 2 shows exceptional $\mathrm{cm}$ scale euhedral grains of celestite filling shell cavities. Bure 4, 5 and 6 contain remnant forms of shells filled with silica (mainly chalcedony with scarce quartz). Bure 7 and 8 consist of homogeneous claystone. Bure 7 contains two cm-scale nodules of pyrite. Bure 8 shows scarce entire cm-sized specimens of bivalve, Terebratula and Rhynchonella. Two of these carbonate shells were previously characterized (Lerouge et al., 2010b). 


\section{Methods}

\subsection{Mineral characterization}

Optical observations were performed using an Olympus $\mathrm{BH} 2$ microscope under transmitted and reflected lights. The size of mineral grains and particles were measured under the microscope using the Archimed $^{\circledR}$ software calibrated with a micrometer. The range of size range given for each diagenetic phases are approximate and only given for information.

Observations and analyses with Scanning electron microprobe (SEM) were performed on polished thin sections of samples on a JEOL JSM 6100 coupled with an energy dispersive spectrometer (Kevex Quantum) tuned at $25 \mathrm{kV}$. Prior to analysis, a 10-20 nm thick carbon layer was sputtercoated on thin polished sections (Edwards Auto 306).

Observations with Transmission Electron Microscope (TEM) were performed on a Phillips CM20 with a CCD Gatan camera, at $200 \mathrm{kV}$. TEM samples were prepared by dispersing the powdered samples in alcohol using ultrasonic treatment, dropping them onto a porous $\mathrm{C}$ film supported on a Cu grid, and then drying them in air.

Cathodoluminescence (CL) was used to identify Ca-carbonate polymorphs (aragonite and calcite) and to distinguish carbonate biomineralization and diagenetic calcite. The luminescence characteristics of carbonate minerals are controlled by the relative abundances of rare earth elements (REE), manganese and iron, and by their crystalline framework. The most common extrinsic colors of calcite and aragonite are, respectively, yellow-orange to orange and yellowgreen to green. As a consequence, CL measurements enable to distinguish easily these two polymorphs of $\mathrm{CaCO}_{3}$. The system used was a cold cathode Cathodyne from OPEA Society (Laboratoire Optique Electronique Appliquée). The electron beam has adjustable energies up to 26 $\mathrm{keV}$ and currents up to 250 IA. The cathodyne is mounted on a Olympus microscope allowing magnification up to 10 . The system is equipped with a JVC KYF75U tri-CCD digital camera. The three $12 \mathrm{~mm}$-sized sensors have a resolution of $1360 \quad 1024$ pixels.

Spot analyses of carbonates, silicates and sulphates were performed on polished thin section of samples covered with a carbon coating, using a CAMEBAX SX50 electron microprobe with an acceleration voltage of $15 \mathrm{kV}$, a current beam of $12 \mathrm{nA}$ and a 1-2 $\mu \mathrm{m}$ beam width. Peak and background counting times were $10 \mathrm{~s}$ for major elements and $40 \mathrm{~s}$ for $\mathrm{Ba}, \mathrm{Sr}$ and $\mathrm{S}$. Detection limits were 970 ppm for Ba, 570 ppm for Fe, 545 ppm for Mn, 160 ppm for Sr and 210 ppm for S. Electron microprobe analyses of pyrite were performed with an accelerating voltage of $20 \mathrm{kV}$ and a current beam of $20 \mathrm{nA}$. Standards used included both well-characterized natural minerals and synthetic oxides. Matrix corrections were made with a ZAF computing program. 


\subsection{Stable isotopes}

Pyrite and celestite were separated by handpicking under binocular, and then grounded in an agate mortar. Sulphur isotope analyses were performed on about 200-300 $\mu \mathrm{g}$ of pyrite and celestite using an elemental analyzer coupled to a delta-Plus CF-IRMS. Oxygen isotope analyses were performed on about $300 \mu \mathrm{g}$ of celestite with an elemental analyzer consisting of a high temperature oxidizer coupled to a Delta-plus CF-IRMS.

Calcite, dolomite and siderite were selectively extracted from about $400 \mathrm{mg}$ of bulk rock by acid attack with pure phosphoric acid. Calcite was extracted first by reaction at $25^{\circ} \mathrm{C}$ for $4 \mathrm{~h}$ (McCrea, 1950), dolomite and ankerite were extracted second by a reaction at $50{ }^{\circ} \mathrm{C}$ for $48 \mathrm{~h}$, and siderite was extracted third by a reaction at $100{ }^{\circ} \mathrm{C}$ for $48 \mathrm{~h}$, following Rosenbaum and Sheppard (1986). $\mathrm{CO}_{2}$ samples obtained in this way were analysed for their isotopic compositions using a Delta $\mathrm{S}$ Finnigan-Mat gas-source mass spectrometer.

Silica phases were separated by handpicking then cleaned using a $\mathrm{HCl} 25 \%$ solution and dried at $50{ }^{\circ} \mathrm{C}$. Oxygen isotopes were measured on silica using the conventional method of Clayton and Mayeda (1963). About ten $\mathrm{mg}$ of silica were used for analysis. The temperature of the preliminary step of the sample degassing was fixed at $50^{\circ} \mathrm{C}$.

All the results are reported in $\delta$ units relative to international standards, defined by: $\delta=$ $\left(R_{\text {Sample }} / R_{\text {Standard }}-1\right) \times 1000 \%$, where $R$ is the measured isotopic ratio in the sample and in the standard: SMOW for oxygen, PDB for carbon and CDT for sulphur. Reproducibility was $\pm 0.2 \%$ for oxygen and carbon and $\pm 0.3 \%$ for sulphur. 


\section{Petrology}

Petrological work consisted in describing the major mineralogical and textural characteristics of the studied samples in order to establish the diagenetic mineral sequence in the COx unit. Studied samples were divided in two groups, limestone and claystones on the basis of their clay content, according to previous works (Rousset and Clauer, 2003; Yven et al., 2007). The two carbonate-rich claystone samples (EST12436 and EST20714) were included in the claystone group. Exceptional macroscopic textures, mineral and fossils are separately described. A preliminary diagenetic sequence is established both for limestone and claystones. A complete diagenetic sequence is presented further, after integration of chemical and isotopic data.

\subsection{Petrographic descriptions}

\section{General characteristics of COx samples - carbonate claystones}

Samples of claystone from the C2a and C2b appear dark greenish, homogeneous, and very finegrained; they contains rare pyritous bioturbations (Figure $2 a$ ) and fossils (Figure $2 b$ ). The matrix consists of dominant detrital mineral particles and bioclasts, which are cemented by micritic calcite associated with minor framboidal or euhedral pyrite (Figure 2c). Detrital mineral particles are composed of dominant $<2 \mu \mathrm{m}$-sized clay particles, $10-50 \mu \mathrm{m}$-sized grains of dominant quartz and minor K-feldspar, and rare 10-50 $\mu$ m-long flakes of muscovite and chlorite, which underline the bedding. Backscattered electron images of framboidal pyrite in several samples show that framboids consist of numerous micronic euhedral pyrite recovered by a fine coating of calcite and organic matter (Figure $2 \mathrm{~d}$ ). Rutile and ilmenite occur as rare $<5 \mu \mathrm{m}$-sized grains. Detrital mineral particles do not show significant sign of dissolution under the microscope, except ilmenite grains.

Bioclasts essentially occur as 10 to $50 \mu \mathrm{m}$-sized clasts of colourless carbonate shells and tests, more rarely as calcium phosphate clasts showing a specific honey colour, and as 50-200 $\mu \mathrm{m}$-sized black particles of organic matter (Figure 2c). Among carbonate clasts, shells of bivalves (posidonomya and undetermined bivalves) and brachiopods, and tests of echinoderms were identified in the samples of this study. Among calcium phosphate clasts, two mm-sized fossils filled with framboidal pyrite in sample EST5724 were identified as tooth of pycnodonts already described in the Cox unit elsewhere in the Paris Basin or as tooth of crustacean decapods found in the Kimmeridgian marls and limestones overlying the Cox unit at Bure (Carpentier et al; 2006). Calcium phosphate clasts do not show significant sign of dissolution under the microscope. On the contrary, an important proportion of the carbonate bioclasts is partially dissolved or recrystallized into micritic calcite and occasionally pyrite. 
Intergranular pores larger than $10 \mu \mathrm{m}$ and disseminated in the matrix are filled by 10-60 $\mu \mathrm{m}$-sized euhedral limpid grains of calcite (Figures 2c, 2e), dolomite (Figure 2f) and scarce deep-green 10-50 $\mu \mathrm{m}$-sized clusters of glauconite (Figure $2 \mathrm{c}$ ). Siderite occurs as 10-50 $\mu \mathrm{m}$-sized anhedral to subeuhedral grains disseminated in the matrix of samples EST5724 and EST25380 (Figure 2g). Several euhedral grains of calcite and dolomite show growth zoning with $\mu \mathrm{m}$-sized pyrite at their interface (Figure 2f). The residual pores in the largest bioclasts $(50-200 \mu \mathrm{m})$ are partially filled by pyrite and micritic calcite on their rims, and by a limpid and 10-50 $\mu \mathrm{m}$-sized calcite (microsparite) in their core. In sample K119, few anhedral to euhedral 10-50 $\mu \mathrm{m}$-sized grains of sphalerite occur with microsparite (Figures 2h, 2i). In samples EST5554, EST5724 and K119, celestite occurs as 5-20 $\mu \mathrm{m}$ sized crystals associated with calcite infilling a microfossil test.

\section{General characteristics of COx samples - silty limestones}

Samples of silty limestone are hard, greyish, homogeneous and fine-grained, and do not exhibit bedding (Figure 3a). The matrix consists of dominant micritic calcite containing detrital $<2 \mu \mathrm{m}$-sized clay particles, quartz grains and numerous bioclasts which are partially to entirely recristallized into calcite associated with framboidal pyrite (Figure $3 \mathrm{~b}$ ). Bioclasts are dominantly carbonate tests of foraminifers. Shells of bivalves, echinoderms, and brachiopods are more heterogeneously distributed. Glauconite occurs as numerous disseminated green clusters in all the limestone samples. In sample $\mathrm{K} 108$, glauconite is present in the core of a $30 \mu \mathrm{m}$-sized cavity rimmed by micritic calcite with minor pyrite (Figure 3c). The largest pores (10-50 $\mu \mathrm{m})$ in clay-rich zones contain limpid calcite (microsparite), whereas the largest bioclasts (50-200 $\mu \mathrm{m}$ ) are filled by limpid calcite, dolomite followed by minor celestite (Figures $3 d, 3 e)$. Chalcedony is rarely present, as late phase filling largest pores with rims of micritic calcite (Figure $3 f)$.

\section{Pyritous ammonites}

Three specimens of pyritous cm-sized ammonites separated in samples EST5738, EST26479 and EST25380 (bottom of the C2b sub-unit) were cut in half and polished to observe their internal structure (Figure 4a). On the three polished sections, the ammonite shell is partially preserved as remnant fragments of calcium phosphate, whereas septa are entirely replaced by limpid calcite (Figure 4b). Mud is present in core of the shell, whereas the chambers (camerae) are filled with coalescent framboids of pyrite mixed with euhedral pyrite grains, sparitic calcite, celestite and minor euhedral crystals of sphalerite (Figured $4 b, c$ ). Several crystals of sphalerite contain inclusions of framboidal pyrite (Figure 4d).

\section{Pyritous nodules in sample Bure 7 from the gallery}

Two pyritous cm-sized nodules of the sample Bure 7 were cut in half and polished. First nodule is fully built-up with coalescent framboids of pyrite showing calcite-filled cracks having a radial orientation. The second nodule is composed of remnant organic structures surrounded by 
coalescent framboids of pyrite (Figure 4e). The main remnant organic structure is reworked by polyphased micro-cracks sub-parallel and perpendicular to it (Figure 4f). The micro-cracks are bordered firstly by sub-euhedral to euhedral pyrite, and secondly by elongated euhedral grains of marcasite. Organic structures are partially pyritized with traces of galena [PbS] (Figure $4 \mathrm{~g}$ ). The residual porosity is filled with calcite and celestite (Figure $4 \mathrm{~h}$ ).

\section{Pyritous structures associated with brachiopods}

The shell-rich carbonate-rich claystone EST12436 (bottom of the C2b sub-unit) contains pyrite layers and several specimens of brachiopods (Figures 5a, 5b). Tangential and longitudinal sections through well preserved brachiopod shells provide evidence of punctuate brachiopod (probably Terebratulid) with elliptic punctuae fully crosscutting the multi-layer low-angle fibrous shell wall and filled with micritic calcite and framboidal pyrite (Figures 5a, 5c).

Residual cavity of the shell has a geopetal fill that consists of internal mud sediment and diagenetic minerals: microsparite to sparite on the rims, and celestite and minor sphalerite in the core (Figures $5 c-e$ ). A sphalerite mass encapsulates an euhedral dolomite grain (Figure 5d). Complex organic structures are observed in the longitudinal section through the both valves of the brachiopod and in pyrite layers (Figures $5 f-h$ ). Organic matter is partially degraded and intimately associated with mmthick pyrite layers and $\mu \mathrm{m}$-sized barite underlying ancient organic structures (Figures $5 \mathrm{f}-\mathrm{g}$ ). A part of the pyrite layers is broken and crosscut by barite veinlet (Figure $5 \mathrm{f}$ ); residual porosity is filled with calcite, $\mu \mathrm{m}$-sized crystals of celestite and sphalerite. Backscattered electron image of celestite crystals provides evidence of Ba-Sr zoning (Figure 5h).

\section{Entire shells of bivalve and rhynchonella in sample Bure 8 from the gallery}

Three entire specimens - rhynchonella, bivalve and Terebratula, were extracted from the carbonateclay matrix of sample Bure 8 , and mounted in thin polished sections. Observations with optical microscope, electronic microscope and cathodoluminescence were performed to define the shell organization, its recrystallization state and the type of calcium carbonate polymorph. Rhynchonella shell is well-preserved (Figure 6a-b). Cathodoluminescence image indicates that shell consists of elongated aragonite (green colour) partially recrystallized into calcite (red colour) (Figure 6c). Observations of bivalve shell provide evidence of the wholly recrystallization of bio-carbonate into diagenetic calcite (dark red in cathodoluminescence) containing numerous inclusions of celestite (Figures 6d-f). Cross-section of Terebratula shell provides evidence of remnant internal cell structures filled by diagenetic pyrite in a shell composed of fine prismatic organic structures filled by bio-carbonate (Figures $6 \mathrm{~g}$-i).

\section{Replacements and infilling of shells in the samples Bure 1 to Bure 6 from the gallery}


Bure 1, 2 and 3 are samples of hard greyish homogeneous limestone containing several $\mathrm{cm}$-sized bivalve shells filled with silica and celestite (Figure 7a). The carbonate matrix consists of micritic calcite with numerous partially to entirely recrystallized carbonate bioclasts (foraminifers, echinoderms, bivalve). Longitudinal sections of bivalve shell show remnant palissadic (prismatic) calcite partially dissolved and replaced by fibrous chalcedony (Figure 7b). Bivalve inner-part is filled with large euhedral crystals of calcite (sparitic calcite) growing on the shell and a central part of chalcedony and celestite (Figure 7c). Sparitic calcite encapsulated euhedral grains of dolomite and glauconite (Figure 7d). Rare structures of framboidal pyrite occur in celestite and calcite, without any evidence of mineral disequilibrium (Figure 7e). Irregular contact between chalcedony and celestite and dolomite, and celestite and dolomite inclusions enclosed in chalcedony, observed in Bure 3 indicate a partial dissolution of celestite and dolomite (Figure 7f).

Bure 4, 5 and 6 are quite similar to Bure 1,2 and 3. They contain $\mathrm{cm}$-sized bivalve shells showing an important replacement of calcite by chalcedony. Bure 6 also contains small euhedral quartz growing on the replaced shell. Celestite was barely detected.

\section{Crack infillings}

Carbonate-rich claystone sample EST20714 contains a cm-sized celestite crack crosscutting the bedding of the rock (Figure $8 \mathrm{a}$ ). This vein is crosscut by fine mm-sized veinlets of $\mu \mathrm{m}$-size grained calcite, and one of these borders is crosscut by a fine mm-sized veinlet of chalcedony (Figure 8b). No mineralogical change was observed at claystone matrix/crack contact.

Limestone sample EST5485 contains mm-thick cracks rimmed first by limpid fine-grained calcite and secondly by euhedral dolomite with residual pores filled by celestite (Figures $8 \mathrm{c}-\mathrm{d}$ ). A $100 \mu \mathrm{m}$ thick veinlet of chalcedony crosscut dolomite and celestite. The matrix essentially consists of finegrained greyish calcite with minor quartz grains and foraminifer tests which are replaced and filled with limpid calcite.

Limestone sample EST20433 contains a $5 \mathrm{~mm}$-thick crack or vug rimmed firstly by limpid finegrained calcite, secondly by euhedral coarse-grained sparite then filled by euhedral mm-scale quartz (Figure 8e-f). A fine veinlet of chalcedony crosscut the border of the crack. The contact between chalcedony and calcite is irregular. The limestone matrix essentially consists of finegrained greyish calcite with minor quartz grains and numerous carbonate clasts which are replaced and filled with limpid calcite.

\subsection{Diagenetic sequence}

Mineralogy and textural relationships allowed determining a preliminary chronology of diagenetic minerals in claystone and limestone relative to major stages of sedimentary history - Eogenesis (just after the sediment deposit), Mesogenesis (compaction and burial) and possibly Telogenesis 
(tectonic events). Major informations were deduced from claystone; complementary data were obtained from limestones.

In all claystone samples, cement of micritic calcite associated with minor framboidal pyrite surrounds all detrital particles, replaces and filled most of the carbonate bioclasts, and is likely the first and the main cementation assemblage formed just after the deposition of the sediment (Eogenesis). Inclusions of framboidal pyrite in euhedral calcite and dolomite suggest that a part of euhedral calcite and dolomite is contemporaneous of the pyrite formation. The mm-thick pyrite layers observed in the sample EST12436 are broken and highly reworked, suggesting that pyrite layer has been affected by the compaction and consequently has been formed before or relatively early during compaction (Eogenesis to early Mesogenesis). The complex texture of pyritous nodule (Bure 7) provides clues for at least two generations of pyrite. The first one corresponds to framboidal pyrite commonly observed in other claystone samples. The second one corresponds to euhedral pyrite associated with marcasite growing on the walls of micro-cracks perpendicular and sub-parallel to remnant organic structures, and sediment bedding. This latter is consequently formed later during compaction (Mesogenesis). Microsparite, sphalerite and minor celestite crosscutting pyrite layers in sample EST12436, infilling residual cavities in pyritous ammonites (EST5738, EST25380 and EST26479) and small bioclasts (K119), and filling core of cracks in pyritous nodule (Bure 7), suggests that these minerals are formed later than the both generations of pyrite, i.e. Mesogenesis. The celestite presence within cracks core surrounded by microsparite suggests that celestite is formed later than microsparite. A euhedral grain of dolomite is surrounded by sphalerite in sample EST12436, confirming that euhedral dolomite is formed before sphalerite. The observed celestite crack crosscutting the bedding in claystone sample EST20714 indicates that this celestite is formed later than the major compaction stage (Mesogenesis). Veinlets of finegrained calcite and of chalcedony crosscutting celestite are consequently formed later than celestite crack. Calcite veinlet crosscut chalcedony veinlet, indicating that calcite is formed later than chalcedony.

In all the claystone samples, carbonate bioclasts are partially replaced by cement of micritic calcite with framboidal pyrite and by limpid microsparite, indicating that dissolution of carbonate bioclasts is slow and is effective from the deposition to the burial at least. Glauconite and siderite are present in the clay matrix but never in infillings and cracks, it can be hypothesized that they are formed before the major stage of compaction of formation of cracks (eogenesis to early mesogenesis).

In all limestone samples, the important replacement of carbonate bioclasts by micritic calcite with minor framboidal pyrite provides also evidence of a major micritisation stage beginning just after the deposition (eogenesis). Limpid calcite (microsparite) filling bioclasts and also as rims growing on replaced shells and tests could be also attributed to early stages of replacement of bio-carbonate 
(aragonite and bio-calcite), corresponding to eogenesis and early mesogenesis. The position of glauconite in the diagenetic sequence is unclear. However the glauconite is always present in the limestone matrix, never in infillings and cracks, and exceptionally enclosed in a dolomite grain. It strongly suggests that it is formed relatively early in the diagenetic sequence, at least before dolomite in cracks. Rare cracks (EST5485) and bioclasts cavities (Bure 1 to Bure 3) filled firstly with limpid calcite, secondly with dolomite on the border and celestite in the core indicate later formation of dolomite and celestite as compared to limpid calcite, during the burial (mesogenesis). They are partly crosscut by chalcedony veinlets and infillings indicative of later chalcedony formation, as compared to dolomite and celestite (mesogenesis).

The limestone sample Bure 2, containing $\mathrm{cm}$-sized bivalve shells, is peculiarly informative on the mineral equilibrium between diagenetic phases. Rare pyrite structures in contact with celestite and dolomite show that pyrite forms earlier than celestite and dolomite. Regular contact between pyrite and celestite suggests that fluid forming celestite remains at equilibrium with early pyrite. To the contrary, chalcedony occurs as replacement of calcite in bioclasts and as infilling crosscutting sparite, dolomite and celestite in bioclast cavities with dissolution contacts between chalcedony and other phases. These observations confirm that chalcedony infilling is formed later than celestite, sparite and dolomite, and from a fluid that was not at equilibrium with them; chalcedony in replacement of bio-calcite is probably earlier than celestite, and not at equilibrium with calcite which it replaces.

A crack filled firstly with sparite then by quartz in the limestone sample EST20433 provides evidence for diagenetic quartz formed later than sparite during burial (mesogenesis). The regular quartz-sparite contact suggests that the quartz precipitated from a fluid remaining at equilibrium with calcite. The crack border is reworked by a chalcedony veinlet without contact between chalcedony and quartz. On the contrary of quartz, chalcedony/sparite contact exhibits dissolution features, demonstrating that chalcedony is formed from a fluid not at equilibrium with calcite, as previously observed in sample Bure 2. Although no textural relationship is observed between chalcedony and quartz, the contrasting contacts with sparite indicates they are not precipitated from the same fluid, and thus are not contemporaneous.

According to observations in claystone and limestone samples, a summary of mineral sequence can be proposed:

1) early diagenesis (eogenesis and early mesogenesis) is marked by an important micritic cementation associated with minor pyrite, euhedral dolomite and glauconite. Textural relationships indicate that glauconite is formed later than pyrite. Rare chalcedony in matrix is formed later than previous diagenetic phases; its formation in replacement of shells in Bure samples suggests it is earlier than minerals filling cavities and cracks. This early replacement of shell favours its resistance to mechanical compaction. 
2) Mesogenesis is marked by filling of cavities and cracks successively by:

- Sparite/dolomite and celestite; sphalerite is associated to this stage in claystone.

- Chalcedony which crosscut celestite,

- Post-celestite calcite only in carbonate-rich claystone EST20714

- Quartz in crack only in limestone EST20433

The occurrence of these phases in cracks clearly indicates they are formed during or later than major compaction.

\subsection{Mineral chemistry}

The petrological study was completed by SEM, TEM observations and EPMA elemental mapping and analyses. The two objectives of this complementary work were first to define the stability of the detrital clay minerals and bioclasts and second to identify chemical evolution of pore water via changes of mineral chemistry (such as in carbonates, pyrite, sulphates).

\section{Clay minerals}

EPMA analyses were performed on detrital clay minerals of the $<2 \mu \mathrm{m}$ fraction deposed on a thin section and on 10-100 $\mu \mathrm{m}$-sized flakes of detrital biotite, muscovite and chlorite, and on diagenetic glauconite observed in polished thin sections of several limestone and claystone samples. Complementary TEM observation was performed on the $<2 \mu \mathrm{m}$ fraction in the sample EST25380 to estimate biotite content and its stability.

Flakes of chlorite and biotite (7 particles out of 70 ) were observed by TEM among the $<2 \mu \mathrm{m}$ particles of illite and illite-smectite mixed layer. Biotite occurred as relatively dark particles of heterogeneous appearance because of numerous associated rutile grains (Figure 9a).

EPMA analyses of clay minerals reported in a $\mathrm{Si} / 4-(\mathrm{Na}+\mathrm{K}+2 \mathrm{Ca})-(\mathrm{Fe}+\mathrm{Mg})$ ternary diagram show that the average composition of the $<2 \mu \mathrm{m}$ fraction belongs to the triangular field of illite and illitesmectite mixed layer (Figure 9b). Biotite analyses plot along two lines: a first line between biotite and chlorite end-members interpreted as biotite partially altered to chlorite ( $\mathrm{K}$ depletion at constant $\mathrm{Fe}-\mathrm{Mg}$ ), and a second line toward the illite end-member, attributed to illitisation of biotite (iron depletion at constant $\mathrm{K}$ ). Chemical cross-sections through biotite grains show the chemical evolution of biotite into illite at the rims of the grain, marked by the significant loss of iron and of titanium. The Ti content measured in the core of the biotite particles is relatively high (up to $3 \mathrm{wt} \%$ ), in agreement with its metamorphic origin.

Chlorite analyses plot in the field of chlorite, but analyses across several particles plot on a line toward a biotite end member, suggesting that chlorite likely results from the biotite alteration. 
Muscovite analyses form a line typical for muscovite-phengite solid solution. However, some analyses plot in the illite field, suggesting muscovite illitisation.

Glauconite chemical composition has low $\mathrm{K}_{2} \mathrm{O}$ (6.07- 7.43 wt \%) and high $\mathrm{FeO}(14.12-16.58$ wt \%) contents.

\section{Carbonates}

EPMA analyses were performed on carbonate bioclasts and the different generations of diagenetic carbonates (Table 1).

Among bioclasts, EPMA analyses were performed on calcite from well-preserved terebratula shell, partially recrystallized rhynchonella and recrystallized bivalve shells in the sample limestone Bure 8 , and on undetermined bioclasts of the claystone sample EST25380. Calcite from bioclasts is a lowmagnesian and iron-poor calcite containing significant sulphur (up to $0.16 \mathrm{wt} \% \mathrm{~S}$ ) and strontium (up to 0.14 wt\% Sr). Sulphur and strontium contents decrease with the degree of replacement of biocalcite by diagenetic calcite.

Micritic calcite has a relative homogeneous composition in limestone samples $\left(\mathrm{Ca}_{0.978-0.980} \mathrm{Fe}_{0.002-}\right.$ $\left.0.003 \mathrm{Mg}_{0.016-0.019} \mathrm{CO}_{3}\right)$ and in claystone samples $\left(\mathrm{Ca}_{0.957-0.968} \mathrm{Fe}_{0.011-0.012} \mathrm{Mg}_{0.020-0.029} \mathrm{CO}_{3}\right)$. It is a low magnesium calcite (LMC) with traces of $\mathrm{Mn}$ and Sr. Micritic calcite in claystone is slightly enriched in $\mathrm{Fe}, \mathrm{Mg}$ and $\mathrm{Mn}$ as compared to micritic calcite in limestone.

Microsparite filling cavities has a composition quite similar to micritic calcite in the limestone sample EST5485 and shows a slight iron-enrichment in claystone samples $\left(\mathrm{Ca}_{0.943-0.968} \mathrm{Fe}_{0.015-0.038} \mathrm{Mg}_{0.016-}\right.$ $\left.0.027 \mathrm{CO}_{3}\right)$.

Calcite in veinlet crosscutting celestite crack in the carbonate-rich claystone sample EST20714 has a chemical composition similar to microsparite $\left(\mathrm{Ca}_{0.96-0.968} \mathrm{Fe}_{0.020} \mathrm{Mg}_{0.012} \mathrm{CO}_{3}\right)$.

All three populations of diagenetic calcite have lower strontium contents than bio-calcite.

Euhedral dolomite has in general a slightly higher $\mathrm{Ca} / \mathrm{Mg}$ in limestone $\left(\mathrm{Ca}_{0.55} \mathrm{Fe}_{0.01} \mathrm{Mg}_{0.44} \mathrm{CO}_{3}\right)$ than in claystone $\left(\mathrm{Ca}_{0.48-0.50} \mathrm{Fe}_{0.01} \mathrm{Mg}_{0.49-0.51} \mathrm{CO}_{3}\right)$. Elemental mapping and EPMA analyses show a significant iron enrichment of the $\mu \mathrm{m}$-thick rim of euhedral grains (up to $6.1 \mathrm{wt} \% \mathrm{FeO}$ corresponding to a structural formulae $\mathrm{Ca}_{0.54} \mathrm{Fe}_{0.07} \mathrm{Mg}_{0.38} \mathrm{CO}_{3}$ ) (Figure 10).

Dolomite bordering cracks in the limestone sample EST5485 has the same $\mathrm{Ca} / \mathrm{Mg}$ ratio than euhedral dolomite in limestone, but significant higher iron content (up to $4.8 \mathrm{wt} \% \mathrm{FeO}$ corresponding to $\mathrm{Ca}_{0.54} \mathrm{Fe}_{0.06} \mathrm{Mg}_{0.38} \mathrm{CO}_{3}$ ).

Siderite observed in sample EST25687 is not a pure $\mathrm{FeCO}_{3}$ but contains $\mathrm{Mg}$ and $\mathrm{Ca}\left(\mathrm{Fe}_{0.66} \mathrm{Ca}_{0.12}\right.$ $\mathrm{Mg}_{0.21} \mathrm{CO}_{3}$ ), which place it in the sideroplesite family, according to Mozley (1989).

\section{Pyrite}


EPMA analyses (major and trace elements) were performed on disseminated framboidal pyrite in claystones and on massive pyrite of nodules, pyrite layer and pyritous ammonite of the sub-unit C2b (Table 2). All the analyses have roughly pyrite stoichiometry, even when the sum of elements is lower than 100 wt \%, due to the presence of organic matter and micronic calcite.

$\mathrm{As}, \mathrm{Co}, \mathrm{Ni}$ and $\mathrm{Pb}$ are main trace elements incorporated in pyrite; $\mathrm{Cu}$ and $\mathrm{Zn}$ are present in infratraces. There is no significant chemical variation in pyrite disseminated in matrix from $\mathrm{C} 2 \mathrm{~b}$ and $\mathrm{C} 2 \mathrm{c}$ sub-units, for $\mathrm{Co}, \mathrm{Pb}, \mathrm{Cu}, \mathrm{Ni}$ and $\mathrm{Zn}$, whereas As average content decreases from $\mathrm{C} 2 \mathrm{~b} 1$ to $\mathrm{C} 2 \mathrm{c}$ unit. The $\mathrm{Co} / \mathrm{Ni}$ ratio, currently used to define the pyrite type in the literature provides evidence of two chemical populations depending of its habitus (Figure 11). Pyrite in nodules and pyritous ammonites from the sub-unit C2b1 is Co-poor ( $<500$ ppm) and has generally a low $\mathrm{Co} / \mathrm{Ni}$ ratio. In contrast framboidal pyrite disseminated in the matrix of claystones of the COx unit, whatever the sub-unit, is richer in Co (500-1400 ppm) and has generally a Co/Ni ratio higher than 1.

\section{Sulphates}

Complex chemical zoning of $\mathrm{Ba}-\mathrm{Sr}$ sulphate grains is evidenced from elemental mapping, backscattered electron images and EPMA analyses. Rare barite observed in the claystone sample EST12436 contains significant amounts of strontium $(\mathrm{Sr} /(\mathrm{Ba}+\mathrm{Sr})$ ratio up $\sim 0.19)$. Celestite contains no barium in limestone samples and variable barium contents in claystone samples, with a $\mathrm{Ba} /(\mathrm{Ba}+\mathrm{Sr})$ ratio ranging from 0.07 to 0.16 .

\section{Recorded mineral and chemical changes}

Concerning the clay fraction, observations and analyses of clay particles do not indicate signs of destabilisation, with exception for infra-traces of biotite.

Concerning the carbonate fraction, data indicate 1) diagenetic carbonates are poorer in $\mathrm{S}$ and $\mathrm{Sr}$ than detrital carbonate bioclasts, 2) diagenetic carbonates formed at the end of eogenesis and during mesogenesis are richer in iron than early diagenetic micritic calcite and euhedral dolomite, and 3) the iron-enrichment of late diagenetic carbonates is more important in claystone samples than in limestone ones.

EPMA data on pyrite provide evidence of two chemical populations. Early diagenetic pyrite disseminated in matrix or filling bioturbation contains 500-1400 ppm Co and has Co/Ni ratio higher than 1. On the contrary pyrite in nodules and pyritous ammonites from the sub-unit C2b1 is Co-poor (<500 ppm) and has a low Co/Ni ratio.

Late diagenetic celestite occurring through all the $\mathrm{COx}$ unit has $\mathrm{Ba}-\mathrm{Sr}$ chemical zoning in claystone samples, and is pure in limestone samples. 


\section{Stable isotopes}

$(\mathrm{C}, \mathrm{O}, \mathrm{S}, \mathrm{Sr})$ stable isotopes were performed on diagenetic minerals of the mineral sequence in order to determine the origins of pore waters along the geological times, and to discuss processes of formation of diagenetic minerals. The analyses were performed on mineral separates when it was possible, i.e. pyrite, celestite, chalcedony, dolomite and calcite in cracks. $(C, O)$ isotopes on diagenetic carbonates disseminated in the matrix were performed on bulk matrix using selective extraction procedure according to Rosenbaum and Sheppard (1986).

\subsection{Carbon and oxygen isotopic data of carbonates}

Carbon and oxygen isotopic compositions of calcite, dolomite and siderite were measured on three samples of bulk rock, on dolomite filling large bioclast in limestone sample EST5433, and on late calcite crosscutting the celestite crack of the carbonate-rich claystone sample EST20714. Results are given in Table 3 and reported in a $\delta^{18} \mathrm{O}$ and $\delta^{13} \mathrm{C}$ diagram (Figure 12).

Calcite analysed in the bulk rocks correspond to a mixing of carbonate bioclasts (well-preserved and recrystallized) and micritic calcite with minor euhedral calcite and microsparite. $\delta^{18} \mathrm{O}$ and $\delta^{13} \mathrm{C}$ values range between +27.7 and $+28.0 \%$ (SMOW) and between +1.8 and $+2.3 \%$ (PDB), respectively.

Dolomite analysed in bulk rocks essentially corresponds to euhedral dolomite. $\delta^{18} \mathrm{O}$ and $\delta^{13} \mathrm{C}$ values of dolomite range between +27.4 and $+27.8 \%$ (SMOW) and between +1.0 and $+2.4 \%$ (PDB), respectively. Values of calcite and dolomite in bulk rocks are quite similar, and are consistent with marine carbonates.

Siderite in bulk samples EST25380, EST25687 and EST5724 that have a wide range of $\delta^{18} \mathrm{O}(+25.9$ to $+29.5 \%(\mathrm{SMOW}))$ and $\delta^{13} \mathrm{C}$ values $(-7.3$ to $+1.2 \%$ PDB $)$ is slightly ${ }^{13} \mathrm{C}$-depleted relative to calcite and dolomite.

$\delta^{18} \mathrm{O}$ and $\delta^{13} \mathrm{C}$ values of dolomite filling large bioclast in limestone sample EST5433 $(+27.4$ and +2.4 $\%$ respectively) are comparable to values of calcite in bulk rocks, and is slightly ${ }^{13} \mathrm{C}$-richer than dolomite in bulk rocks.

Calcite crosscutting celestite crack in sample EST20714, has a $\delta^{18} \mathrm{O}$ of $+19.6 \%$ (SMOW) and a $\delta^{13} \mathrm{C}$ of $+0.1 \%$ (PDB), and is significantly depleted in ${ }^{18} \mathrm{O}$ relatively to calcite in the matrix.

\subsection{Sulphur isotopic data on pyrite}

Pyrite was separated from fifteen samples of the sub-units C2b and C2c. Twelve separates consist of early framboïdal pyrite filling bioturbations and bioclasts, two are of early framboïdal pyrite disseminated in interstitial, micritic cement and one is of mm-thick pyrite layer in the shell-rich 
carbonate-rich claystone EST12436. Data are given in Table 3. $\delta^{34} S$ values of framboidal pyrite, both filling areas of bioturbation and bioclast and disseminated, range between -38.0 and $+34.5 \%$ (CDT). The mm-thick pyrite layer shows high $\delta^{34} S$ value of $+74.0 \%$. Reported in the lithostratigraphic column, $\delta^{34} \mathrm{~S}$ values of framboidal pyrite are negative in the lower part of the $\mathrm{C} 2 \mathrm{~b}$ sub-unit and in the C2c sub-unit, whereas they increase to positive values in the upper part of the C2b sub-unit (Figure 13).

\subsection{Sulphur and oxygen isotopic data on celestite}

Celestite filling bioclasts in limestone samples (EST5433, Bure 1, Bure 2, Bure 3) and filling cracks (limestone EST5485 and carbonate-rich claystone EST20714) was separated and analysed for sulphur, oxygen (Table 3); strontium isotope data on these celestite separates were acquired in a previous work (Lerouge et al., 2010a). Celestite filling bioclasts in limestone samples have relatively homogeneous isotopic signatures $\left(\delta^{34} \mathrm{~S} \sim 22.5-25.8 \% \mathrm{CDT}, \delta^{18} \mathrm{O} \sim 19.5-20.3 \%\right.$, and ${ }^{87} \mathrm{Sr} /{ }^{86} \mathrm{Sr}$ ratios $\sim 0.706872-0.706945)$. Celestite filling cracks in the two samples EST5485 and EST20714 have two different (O, S, Sr) isotopic signatures (EST20714: $\delta^{34} \mathrm{~S}=31.4 \% \mathrm{CDT}, \delta^{18} \mathrm{O}=20.7 \%$, and ${ }^{87} \mathrm{Sr} /{ }^{86} \mathrm{Sr}$ ratio 0.707040; EST5485: $\delta^{34} \mathrm{~S}=27.3 \% \mathrm{CDT}, \delta^{18} \mathrm{O}=21.2 \%$, and ${ }^{87} \mathrm{Sr} /{ }^{86} \mathrm{Sr}$ ratio $~ 0.707373$ ).

\subsection{Oxygen isotopic data of chalcedony and authigenic quartz}

$\delta^{18} \mathrm{O}$ values of structural oxygen were measured on the following silica separates: three separates of chalcedony replacing carbonate shell (Bure 1, 4 and 5), a separate of chalcedony infilling bioclast and crosscutting celestite and dolomite (Bure 3), a separate of quartz growing on chalcedony which replaces carbonate shell (Bure 6), two separates of chalcedony crosscutting celestite cracks (EST5485 and EST20714), and a separate of euhedral quartz filling crack in sample EST20433. $\delta^{18} \mathrm{O}$ varied between +19.8 and $+31.8 \%$ (Table 3 ). The isotopic results seem related to the petrographic groupings. Chalcedony replacing bivalve shells shows high $\delta^{18} \mathrm{O}$ values, between +31.3 and $+31.8 \%$. Chalcedony infilling bioclast and partly crosscutting celestite and dolomite has $\delta^{18} \mathrm{O}$ values between +26.1 and $+28.0 \%$. Euhedral quartz infilling crack in the limestone sample EST20433 has a significantly lower $\delta^{18} \mathrm{O}$ value of $+19.8 \%$.

\section{Discussion}

Petrological data, textural relationships and mineral chemistry, were informative of phase stability, texture modifications, diagenetic sequence and consequently chemical evolution of pore water along geological times. These informations bring constraints on porewater chemistry models. The mineral stability and texture modifications are also important information to constraint diffusion 
processes through the $\mathrm{COx}$ in natural conditions. Stable isotopes complete this data set by giving information on early sedimentation conditions but also on late diagenetic minerals recording the diffusion of meteoric waters into the COx unit. Combined petrological and isotopic data allowed checking mineral stabilities through fluid changes (marine versus meteoric). Strontium isotopic data, and potentially oxygen isotopes can help to propose a timing of the mineral sequence relative to the lifetime of the sedimentary basin (Figure 14).

\subsection{Detrital minerals and their stability}

Among major detrital phases (clays $<2 \mu \mathrm{m}$, quartz, feldspars and carbonate bioclasts) silicates (illite/muscovite, illite-smectite mixed layers, chlorite quartz and feldspar) show no evidence of dissolution in the claystone. Calcium carbonate bioclasts are recrystallized into calcite or dissolved and replaced by diagenetic phases such as pyrite, chalcedony. Bio-carbonates recrystallization into diagenetic calcite is associated to the liberation of sulphur (reduced sulphur and sulphate) and strontium which were involved in the precipitation of diagenetic pyrite and celestite.

The minor, detrital, iron-bearing phases, ilmenite and biotite appear partially destabilized; Ilmenite breakdown to rutile and biotite breakdown to illite are two reactions that liberate iron which is then used by the formation of diagenetic iron-bearing phases. However the breakdown of these minor iron-bearing phases represents a slight contribution to the iron content in pore water.

Among the bioclastic fraction other than bio-carbonates, minor particles of organic matter and calcium phosphate clasts were identified in the Cox unit, and especially in claystones. Particles of organic matter was partially degraded and consumed by bacterial sulphate reduction. They are often associated with pyrite.

The dissolution of detrital phases contributed to initiate secondary porosity. In the Cox unit, the breakdown of minor detrital micas and accessory ilmenite into secondary clay minerals and rutile, respectively, did not contribute significantly to create porosity. On the contrary, the dissolution of carbonate shells and tests could have initiated secondary porosity.

\subsection{Chemical changes recorded by cements of the diagenetic mineral sequence}

From petrological observations, we deduced that diagenetic phases are not abundant, but that they have contributed to seal most of the residual porosity visible under the microscope. Mineral sequence determined in claystone and limestone samples of the COx unit was completed by the mineral chemistry (Figure 14).

The eogenesis, i.e. just after sedimentation and before any compaction process, is characterized by a major cementation of micritic low-Mg calcite and pyrite, with minor euhedral calcite and dolomite in claystone and limestone (stage 1); euhedral calcite and dolomite are essentially identified in claystone. At the end of this phase, a change of porewater chemistry is recorded by the $\mu \mathrm{m}$-sized 
rims of euhedral calcite and dolomite, especially marked in claystone, the glauconite deposit at the scale of the COx unit, and the siderite presence at the maximum clay zone (stage 2).

According to the textural observations, the rare occurrences of other diagenetic minerals: celestite, sphalerite, chalcedony, associated with late generations of carbonates are formed during the mesogenesis, i.e. during the burial and the compaction of the COx sediments.

Celestite is observed both in claystone and in limestone; however the mineral association, habitus and chemistry are slightly different. Celestite is associated with microsparite and sphalerite filling bioclasts in claystone (EST12436, K119, EST25380, EST26479, EST5738, Bure 7) and without sphalerite in limestone (Bure 3 ). Celestite \pm dolomite filling crack is only observed in the carbonaterich claystone sample EST20714 and in the limestone sample EST5485. EPMA analyses of celestite also provide evidence of significant amounts of $\mathrm{Ba}$ in celestite in claystone, whereas celestite is pure in limestone. Chalcedony replacing and infilling bioclasts, or in veinlets crosscutting celestite is observed in the carbonate-rich claystone and limestone in the upper part of the COx unit (Bure 3, EST5485, EST20714, EST20433).

The presence of cracks only in carbonate rich claystone and in limestone is due to difference of rock competence. Calcite veinlet crosscutting a crack filled with celestite, and chalcedony (EST20714) and quartz filling crack (EST20433) are the two only mineral records of fluids later than chalcedony deposit.

\subsection{Stage 1: - Micritic calcite, pyrite, euhedral calcite and dolomite - Bacterial activity and sedimentation conditions}

\section{Carbonate origin}

Micritic calcite and rare euhedral calcite have low Mg and Fe contents, consistent with a marine environment. The early dolomite deposition has probably to be linked to water loss of clay sediments and expulsion of $\mathrm{Mg}^{2+}$ during burial. $(\mathrm{C}, \mathrm{O})$ isotopic compositions of calcite and dolomite measured in bulk rocks essentially correspond to those of carbonate bioclasts and carbonates of early stage (micritic calcite, euhedral calcite and dolomite). $\delta^{18} \mathrm{O}$ and $\delta^{13} \mathrm{C}$ values of calcite, 27.7$28.0 \%$ SMOW and 1.0-2.3 \% PDB respectively, belong to the field of marine carbonates.

\section{Pyrite deposition}

Framboidal pyrite, euhedral pyrite, and pyritous ammonites and nodules observed in studied samples are different forms common in marine sediments (Böttcher \& Lepland, 2000). Pyritous ammonites and nodules occur in organic-rich, silty and carbonate claystone samples, often associated to shell-beds which are believed to mark pauses in sediment accumulation.

The large $\delta^{34} S$ values of framboïdal pyrite are informative on the early diagenetic conditions. Framboids of pyrite with negative $\delta^{34} S$ values ( -38 to $-25 \%$ CDT) located in the lower part of the 
Cox clay formation were probably formed by bacterial reduction of marine sulphate in an open marine environment, according to literature (Ohmoto et al., 1990; Wortmann et al., 2001; Canfield, 2002). A system open to sulphate, such as the seawater/sediment interface in a marine environment, has a permanent supply of sulphate. The $\delta^{34} S$ of metastable amorphous iron sulphides $\left(\mathrm{FeS}_{\mathrm{m}}\right.$ - not detected in the present study) early formed in the system is determined by the $\delta^{34} S$ of sulphate and the kinetic isotopic fractionation $k_{1} / k_{2}$ between sulphate and $F_{e} S_{m}$, as follows: $\delta^{34} \mathrm{~S}_{\mathrm{FeSm}}=\delta^{34} \mathrm{~S}_{\mathrm{SO} 4}-1000 \mathrm{ln} \mathrm{k}_{1} / \mathrm{k}_{2}$. $\mathrm{FeS}_{\mathrm{m}}$ are metastable and transformed into pyrite during diagenesis; the isotopic fractionation between $\mathrm{FeS}_{\mathrm{m}}$ and pyrite is neglictible (Rickard and Luther III, 2007). Consequently $\delta^{34} S_{\mathrm{Py}}$ is quite close to $\delta^{34} \mathrm{~S}_{\mathrm{FeSm}}$. Maximum value of $\mathrm{k}_{1} / \mathrm{k}_{2}$ fractionation between sulphate and pyrite is estimated to be $\sim 1.055$ from the lowest pyrite $\delta^{34} S$ value $(-38 \%$ ), assuming a $\delta^{34} \mathrm{~S}$ value of $+17 \%$ for Jurassic seawater (Kampschulte and Strauss, 2004). This value is slightly higher than that obtained experimentally by Canfield (2002) or theorically calculated by Rees (1973), but is consistent with values estimated from natural samples (Wortmann et al., 2001; Ohmoto et al., 1990; Werne et al., 2003) and is in agreement with the revised isotope fractionation model for dissimilatory sulphate reduction proposed by Brunner and Bernasconi (2005).

Pyrite with higher $\delta^{34} S$ values were formed in a system closed to sulphate with little or no recharge of marine sulphate such as a regressive marine environment and/or sediment disconnected from the marine domain by overlying sediments. In a system closed to sulphate, the sulphate reduction rate is much more rapid than the rate of $\mathrm{SO}_{4}{ }^{2-}$ supply to the system. The $\delta^{34} \mathrm{~S}$ of the sulphate remaining at a time $t$ in the diminishing reservoir of reacting sulphate can be approximated by a Rayleigh distillation law as follows:

$$
\delta^{34} \mathrm{~S}_{\mathrm{SO} 4(\mathrm{t})}=\delta^{34} \mathrm{~S}_{\mathrm{SO} 4(0)}+1000\left(\mathrm{k}_{1} / \mathrm{k}_{2}-1\right) \ln \mathrm{F}
$$

In these equations, $\delta^{34} S_{\mathrm{SO} 4(\mathrm{t})}$ is the $\delta^{34} \mathrm{~S}_{\mathrm{SO} 4}$ at time $\mathrm{t}, \delta^{34} \mathrm{~S}_{\mathrm{SO} 4(0)}$ is the initial $\delta^{34} \mathrm{~S}_{\mathrm{SO} 4}, \mathrm{k} 1 / \mathrm{k} 2$ is the fractionation factor between sulphate and $\mathrm{FeS}_{\mathrm{m}}$, and $\mathrm{F}$ is the fraction of $\mathrm{SO}_{4}{ }^{2-}$ remaining at time $\mathrm{t}$. There is also an evolution of the isotopic composition of $\mathrm{H}_{2} \mathrm{~S}$ reservoir produced, from which the amorphous iron sulphides precipitate, as a result of this Rayleigh distillation. Very high $\delta^{34} S$ values of pyrite suggest that isotopic evolution of the $\mathrm{H}_{2} \mathrm{~S}$ produced is instantaneously removed from the system by precipitation of iron sulphides and does not mix with subsequent reaction products. The $\mathrm{H}_{2} \mathrm{~S}$ produced at a time $\mathrm{t}$ is at equilibrium with the sulphate remaining at the same time. Consequently, the $\delta^{34} S$ of pyrite produced at a time $t$ is calculated using the sulphur isotopic fractionation between sulphate and $\mathrm{FeS}_{\mathrm{m}}$ (Figure 15):

$$
\delta^{34} \mathrm{~S}_{\mathrm{FeSm}(\mathrm{t})}=\delta^{34} \mathrm{~S}_{\mathrm{SO} 4(\mathrm{t})}-1000\left(\mathrm{k}_{1} / \mathrm{k}_{2}-1\right)
$$

Increasing $\delta^{34} S$ values of pyrite from the lower part $(\mathrm{C} 2 \mathrm{~b} 1)$ to the upper part $(\mathrm{C} 2 \mathrm{~b} 2)$ of the $\mathrm{COx}$ formation indicates a progressive disconnection from the marine domain suggesting that C2b2 corresponds to a period of regression. That is in agreement with previous works (Rousset, 2002; Rousset and Clauer, 2003). The highest $\delta^{34} S$ value recorded by massive pyrite from a mm-thick pyrite layer of the shell-rich carbonate-rich claystone sample EST12436 is consistent with pyrite 
formed by bacterial reduction of residual marine sulphate in a confined and highly evolved system during burial of the sediment. Based on a Rayleigh modelling, such a high value could be obtained by reduction of a pore-water sulphate that retained less than 10-20\% of the initial dissolved sulphate, the other $80-90 \%$ being reduced by bacterial reduction and precipitated as iron sulphides (Figure 15).

From petrographic observations and the sulphur isotopic compositions of pyrite it can be deduced that pyrite formation results from intense bacterial sulphate reduction coupled with organic matter degradation (dissimilatory sulphate reduction) rather than anaerobic oxidation of methane. The alkanes now present in trace amounts in the COx unit have a thermogenic origin and were not generated in the formation itself (Prinzhofer et al., 2009). The various forms of pyrite could be attributed to different reaction pathways. Framboïds of pyrite crystallized after metastable biogenic $\mathrm{FeS}_{\mathrm{m}}$ phases formed where, locally, sulfide production rates were high enough for porewaters to reach supersaturation with respect to $\mathrm{FeS}_{\mathrm{m}}$ (Raiswell, 1982). Instead, rare euhedral forms of pyrite probably crystallized directly from the porewater when saturation was reached for $\mathrm{FeS}_{2}$ and not for FeS $_{\mathrm{m}}$ (Rickard and Luther III, 2007).

\section{Causes of bacterial activity stop}

As burial increased during diagenesis, the bacterial activity recorded by the pyrite precipitation was stopped. The inability of the sulphate reducers to use pore-water sulphate and remaining organic substrates in this sediment is most probably a physical effect related to the pore throat sizes of the COx. Indeed, if we consider the present pore size distribution of the COx (Sammartino et al., 2003; Yven et al., 2007), 60 to $80 \%$ of the porosity is represented by the mesoporosity (3 to $60 \mathrm{~nm}$ ). In the more clayey samples the mesoporosity reaches $94 \%$ of the total porosity. Macroporosity (>60 nm) accounts for less than $6 \%$ of the total porosity. Porosity volumes larger than $1 \mu \mathrm{m}$ (size magnitude of a sulphate reducing bacteria - 0.7 to $3 \mu \mathrm{m}$ according to Brock et al., 1994) are negligible, preventing bacteria populations growth. Because celestite and iron-rich carbonates precipitated after pyrite formation stopped, a lack of sulphate or aqueous iron cannot be evoked. The residual organic-matter content of the formation (1\%) was also not a limiting factor. This effect of pore size in suppressing bacterial activity has been described in a similar environment by Bottrell et al. (2000) and Fredrickson et al. (1997).

\subsection{Stage 2: End of the bacterial activity and ferroan phases - carbonates and glauconite}


The bacterial sulphate reduction processes were complex and controlled not only the deposition of sulphur-bearing phases but also such other diagenetic phases as carbonates and glauconite. Micritic calcite associated with framboïdal pyrite, and euhedral calcite and dolomite which are formed during bacterial activity are not ferroan. According to the observed mineral relationships, ferroan carbonates, which include the outer $\mu \mathrm{m}$-sized rims of euhedral calcite and dolomite, together with siderite, and glauconite are formed later than framboïdal pyrite, i.e. after the end of the activity of sulphate reducing bacteria; that has been already observed in Oxford clay sediments in the UK (Hudson et al., 2001). Ferroan calcite and dolomite are observed in the entire COx unit; however iron enrichment of calcite and dolomite is more important in claystone samples than in limestone samples. Sideroplesite is only observed in the studied claystone samples EST5724 and EST25687 of the C2b1 sub-unit located at depth corresponding to the maximum clay zone.

\section{Iron enrichment of carbonates}

The formation of ferroan carbonates later than pyrite is related to the specific chemical conditions maintained by bacterial activity. During bacterial sulphate reduction there is a high HS concentration, a high $\mathrm{CO}_{2}$ pressure in the system which lowers the $\mathrm{pH}$, and a low iron concentration due to the formation of Fe-sulphides.

For precipitation kinetics reasons, $\mathrm{FeS}_{\mathrm{m}}$ solid compounds precipitate in these systems. However, once bacterial production of $\mathrm{HS}^{-}$ends, $\mathrm{FeS}_{\mathrm{m}}$ dissolves and is replaced by pyrite $\left(\mathrm{FeS}_{2 \mathrm{p}}\right)$ due to the lower solubility of the latter (Rickards and Luther III, 2007). Considering anaerobic conditions, this transformation follows the overall reaction balance (without consideration of any particular molecular mechanism):

$$
2 \mathrm{FeS}_{\mathrm{m}}+2 \mathrm{H}^{+}=\mathrm{FeS}_{2 \mathrm{p}}+\mathrm{Fe}^{2+}+\mathrm{H}_{2}
$$

This reaction is responsible for an increase of $\mathrm{pH}$ and $\mathrm{Fe}$ concentration; two conditions that are favourable to iron carbonate precipitation, provided that bicarbonate concentration is buffered by the presence of calcite:

$$
\mathrm{Fe}^{2+}+\mathrm{HCO}_{3}^{-}=\mathrm{FeCO}_{3}+\mathrm{H}^{+}
$$

\section{Origin of the ferroan phases}

The chemical composition of sideroplesite in studied samples is characteristic of a marine sedimentation and is significantly different from a siderite formed in a fresh water environment (Mozley, 1989). Its $\delta^{18} \mathrm{O}$ is also consistent with a marine origin, whereas its $\delta^{13} \mathrm{C}$ is significantly lower than those of calcite and dolomite in bulk rocks. The ${ }^{13} \mathrm{C}$ depletion may be attributed to a partial contribution in late diagenetic pore waters of carbonate ions derived from the degradation of organic matter during bacterial sulphate reduction.

Glauconite clusters are also a seafloor diagenetic product formed in mildly reducing conditions. The localized reducing environments due to high degradation of organic matter associated with the 
bacterial sulphate reduction in microfauna-rich clay sediments are favourable to the glauconite formation.

\subsection{Stage 3: Ferroan dolomite, sparite and/or celestite filling bioclasts and cracks}

Ferroan dolomite filling bioclasts and cracks is rare and of small size. The limestone sample EST5433 is the only sample in which it has been possible to analyse isotopically ferroan dolomite filling bioclasts. Its $\delta^{18} \mathrm{O}$ and $\delta^{13} \mathrm{C}$ values $(+27.4$ and $+2.4 \%$ respectively) belong to the field of marine carbonates.

On the contrary of ferroan dolomite in bioclasts and cracks, celestite was identified in the studied samples and its size (>200 $\mu \mathrm{m}$, up to $2 \mathrm{~cm}$ ) allowed separating it more easily than ferroan dolomite of this stage. Celestite and accessory barite, precipitated later than pyrite, represent the deposition of residual sulphate dissolved in pore waters after the end of bacterial activity. However, even though dissolved sulphate was still present at the end of the bacterial activity, its concentration in residual pore waters should have not been higher than in the initial fluid, assuming that the system was only fed by marine waters. Simplified thermodynamic calculations show that celestite cannot precipitate from pure seawater but only from sulphate- and/or strontium-enriched seawater. Such enrichment is possible if one takes into account the sulphate and strontium liberated by the partial to entire dissolution of carbonate bioclasts. This assumption is validated by the in-situ crystallization of celestite in recrystallized bivalve shell in the sample Bure 8. These observations are consistent with previous works on celestite deposition in deep-sea carbonate sediments (Baker and Bloomer, 1988; Hoareau et al., 2010).

The $S$ and $O$ isotopic compositions of celestite differ slightly from those of Callovian-Oxfordian seawater (Claypool et al., 1980). The similar variations of $\delta^{34} S$ and $\delta^{18} \mathrm{O}$ are consistent with a seawater sulphate isotopic signature modified by bacterial activity rather than with introduction of an external fluid to the system. The variations of $\delta^{34} S$ are larger than the variations of $\delta^{18} \mathrm{O}$ and there is no good correlation between $\delta^{34} S$ and $\delta^{18} \mathrm{O}$ (Electronic annex EA-1). These data are in good agreement with the few experimental data and modelling presented by Brunner et al. (2005) of the oxygen and sulphur isotopic fractionation of sulphates during bacterial reduction processes. Assuming a Rayleigh modelling of sulphur isotopes in a close system, the celestite values are consistent with a sulphate system in which 15 to $45 \%$ of initial marine sulphate has been reduced by bacteria. The proportion of reduced sulphate deduced from the range of celestite $\delta^{34} S(15-45 \%)$ is significantly lower than those deduced from the range of pyrite $\delta^{34} \mathrm{~S}$ (up to $\sim 75 \%$ in bioturbation and $80-90 \%$ in the pyrite layer of the sample EST12436). This inconsistency is due to the fact that celestite and pyrite did not contemporaneously precipitated from the same fluid. According to textural relationships observed in studied samples and discussion above, celestite precipitated later 
than pyrite from seawater modified by bacterial sulphate reduction with support of sulphate issue of the bio-carbonate dissolution. The carbonate shell recorded the sulphur isotopic signature of seawater. Consequently a sulphate support from the shell dissolution would tend to decrease sulphur and oxygen isotopic signature of the porewaters. Moreover the variations of pyrite $\delta^{34} S$ and the isotopic pyrite-celestite disequilibrium from different samplings suggests that each pyrite framboid cluster evolved as a microsystem independently from the others, probably due to the relative low diffusion of porewater in clay sediment.

\subsection{Stage 4: Chalcedony in replacement of shell, and chalcedony in veinlets crosscutting dolomite and/or celestite}

Oxygen isotopes were used to determine the origin of chalcedony in the COx unit. Isotopic compositions of different chalcedony separates were compared with theorical $\delta^{18} \mathrm{O}$ of silica calculated as a function of the $\delta^{18} \mathrm{O}$ of the fluid and the formation temperature, using the quartzwater oxygen isotope fractionation data of Knauth and Epstein (1976) (Figure 16). Assuming that silica is a late diagenetic phase, the temperature of silica formation can be taken as the temperature of maximum burial, i.e. around $40-50^{\circ} \mathrm{C}$ (Landais and Elie, 1999). The high $\delta^{18} \mathrm{O}$ of chalcedony replacing bivalves suggests it was formed shortly after deposition from marine waters at low temperature $\sim 30^{\circ} \mathrm{C}$ or later from a slightly evolved, ${ }^{18} \mathrm{O}$-enriched marine fluid at $40-50^{\circ} \mathrm{C}$. The $\delta^{18} \mathrm{O}$ values of chalcedony crosscutting celestite in cracks indicate that they were precipitated from a fluid close to or slightly depleted in ${ }^{18} \mathrm{O}$ relative to seawater at the temperature of maximum burial. This chalcedony could be slightly depleted to the earlier generation of chalcedony that replaces bivalves because of mixing with a small meteoric component.

\subsection{Stages 5-6: Calcite veinlet crosscutting a crack filled with celestite, and chalcedony (EST20714) and quartz filling crack (EST20433)}

The calcite crosscutting celestite crack in sample EST20714, with a $\delta^{18} \mathrm{O}$ of $+19.6 \%$ (SMOW) and a $\delta^{13} \mathrm{C}$ of $+0.1 \%$ (PDB), is significantly depleted in ${ }^{18} \mathrm{O}$ relatively to seawater-derived calcite in the matrix. The $\delta^{18} \mathrm{O}$ of the fluid calculated at equilibrium with this calcite at $40^{\circ} \mathrm{C}$ using the calcite-water fractionation of Kim and O'Neil (1997) is around $-5.5 \%$, corresponding to a meteoric signature. The $\delta^{13} \mathrm{C}$ still remains consistent with the signature of the marine carbonates, suggesting that the fluid was initially carbonate-poor and buffered by carbonates of the COx unit concerning the carbon.

Euhedral quartz infilling crack in the limestone sample EST20433 has a $\delta^{18} \mathrm{O}$ value $(+19.8 \%$ lower than chalcedony. The $\delta^{18} \mathrm{O}$ of the fluid calculated at equilibrium with this quartz at $40^{\circ} \mathrm{C}$ using the 
quartz-water oxygen isotope fractionation data of Matsuhisa (1979) is around -7 \%, corresponding to a meteoric signature (Figure 16).

Assuming that this calcite and quartz are formed at temperature of maximum burial, and considering an analytical error on oxygen measurement of $\pm 0.2 \%$, the difference of calculated fluid $\delta^{18} \mathrm{O}$ between calcite and quartz is significant and strongly suggests that calcite is not formed from the same fluid than quartz.

\subsection{Origins and timing of the multiphase cementation in the COx unit}

The $(\mathrm{S}, \mathrm{C}, \mathrm{O})$ isotope data combined with the mineral sequence showed that carbonate cements and pyrite in the fine-grained matrix of claystone (stages 1 and 2), chalcedony replacing shells, carbonates and celestite filling bioclasts and cracks (stage 3) and chalcedony crosscutting celestite (stage 4) precipitated from dominant marine-derived pore waters, whereas late calcite crosscutting celestite (EST20714) and euhedral quartz filling crack (EST20433) (stages 5-6) precipitated from mixing of dominant meteoric water with residual marine-derived fluids.

A timing of diagenetic minerals was approached using previous strontium isotope data on the COx unit (Vinsot et al., 2008; Lerouge et al., 2010) combined with stable isotope data and petrology. ${ }^{87} \mathrm{Sr} /{ }^{86} \mathrm{Sr}$ ratios of carbonate cements in the claystone matrix (stages 1 and 2) range between 0.7069-0.7071 (Lerouge et al., 2010). The lowest values are consistent with Callovian-Oxfordian seawater (0.7068-0.7072; Jones et al., 1994), i.e. the age of sedimentation and beginning of compaction.

The ${ }^{87} \mathrm{Sr} /{ }^{86} \mathrm{Sr}$ ratios of celestite filling bioclasts and cracks (stage 3) provide evidence of two populations of ratio. ${ }^{87} \mathrm{Sr} /{ }^{86} \mathrm{Sr}$ ratios of celestite in samples Bure 1-3 (bioclast infilling), EST5433 (vug infilling) and EST20714 (crack infilling), range between 0.7069 and 0.7070 . These values are similar to lowest values measured in carbonate cements, suggesting that this generation precipitated from Callovian-Oxfordian marine-derived porewaters or remobilizing the $\mathrm{Sr}$ released by the recrystallization of the primary carbonate bioclasts, and consequently recorded chemical conditions of sedimentation and early diagenesis. In any case this population is early diagenetic. Celestite in sample EST5485 (crack infilling) exhibits an ${ }^{87} \mathrm{Sr} /{ }^{86} \mathrm{Sr}$ ratio $(0.7074)$ higher than other celestite separates, suggesting it precipitated later than other celestite infillings. This strontium ratio corresponds to the ratio of Cretaceous seawater (Jones et al, 1994), but also to the present-day strontium isotope signature of the exchangeable fraction in claystones (0.7074-0.7075; Lerouge et al., 2010) and of present-day pore waters in the COx unit (0.7074-0.7076; Vinsot et al., 2008). Consequently strontium isotopes cannot be used to estimate the age of this celestite, due to strontium retardation mechanisms, but also to an in-situ ${ }^{87} \mathrm{Sr}$ expulsed from clays during compaction (Rosenbaum, 1976; Brigaud et al., 2010). 
due to low porosity and permeability of the COx clay unit but also the relative low porosities and permeabilities of the adjacent limestone units (Buschaert et al., 2004; Brigaud et al., 2010). Oxygen isotopes are generally used to date events, but in that case are useful to trace meteoric water inputs in the COx. Meteoric water inputs in the COx unit could have occurred by (i) lateral diffusion of meteoric water into the COx unit at surface during emersion periods, (ii) vertical diffusion of meteoric water from adjacent limestones into the COx unit during and after emersion periods, and (iii) vertical circulations of meteoric water through fault system favouring lateral diffusion of water into the $\mathrm{COx}$ unit, even though the unit is not at the surface, according to the geodynamic scenario undergone by Jurassic sediments from the eastern Paris Basin proposed by Brigaud et al. (2010). Three periods are favourable for meteoric water inputs: the Late Cimmerian Unconformity (LCU) (145-140 Ma), the late Aptian Unconformity (LAU) (112 Ma) and the Oligocene extensional tectonic event (33-23 Ma) (Guillocheau et al., 2000).

The $\delta^{18} \mathrm{O}$ values calculated at equilibrium with calcite (EST20714) and quartz (EST20433), compared with the oxygen isotope profile of pore waters in the COx unit at the same depth indicate that calcite and quartz precipitated from meteoric waters whose oxygen isotopic composition is quite close to those of present-day pore waters at same depth (Figure 17). These two phases consequently would have recorded the late meteoric input after it diffusion into the COx clay unit. Oxygen isotopic variations are representative of the mixing of the successive water inputs into the clay formation, and are due to the high buffering of the clay formation.

\section{CONCLUSION}

The combined mineralogical and sulphur, carbon, oxygen, and strontium isotopic study of CallovianOxfordian claystones improves our understanding of the origin, textures and temporal distribution of late diagenetic phases in the sediment and allows proposing a synthetic and interpreted diagenetic sequence (Figure 16). The early and dominant cement of claystone is micritic, low-magnesium (LMC) calcite. Pyrite in the cement and filling bioturbation is formed by bacterial reduction of dissolved marine sulphates. It is always associated with micritic calcite and residual organic matter, suggesting dissimilatory bacterial reduction processes. The large $\delta^{34} S$ variations of pyrite samples have recorded the conditions of marine sedimentation and are in agreement with results of other clay studies (Rousset and Clauer, 2003). Glauconite and the iron-rich outer rims of euhedral carbonates (calcite, dolomite, and siderite) are formed after pyrite as bacterial activity is ending, from the iron still available in the system. In rare samples, sparry dolomite followed by celestite was deposited as late infilling of vugs and lenses crosscutting bedding. These are formed from residual carbonate and sulphate ions dissolved in diagenetic porewaters, and provided in part from the dissolution of biologically-formed, primary minerals. ${ }^{87} \mathrm{Sr} /{ }^{86} \mathrm{Sr}$ ratios of celestite indicate that it was formed from Jurassic marine waters. Chalcedony occurs replacing bivalve shells, in rare veinlets crosscutting celestite, and filling the last porosity. It is only observed in the middle and the upper 
parts of the COx unit. The oxygen isotopic compositions of different generations of chalcedony indicate they were also formed from marine-derived waters $\left(\delta^{18} \mathrm{O}\right.$ of fluid close to $0 \%$ ). The oxygen compositions of late calcite in the sample EST20714 (C2b2 sub-unit) and of euhedral quartz in the limestone sample EST20433 (C2d sub-unit) indicate that they are the only minerals precipitated from meteoric waters in the COx unit. These late diagenetic minerals in the COx unit recorded the same type of fluids than late diagenetic calcite in adjacent Dogger and Oxfordian limestones which are aquifers (Vincent, 2001; Buschaert et al., 2004), confirming the slow diffusion of meteoric waters from the adjacent aquifers through the COx unit (Girard et al., 2005; Giannesini, 2006). However the scarcity of the late diagenetic minerals indicates the low reactivity of the COx unit with diffusing meteoric waters.

\section{Acknowledgement}

This research has been financially supported by the BRGM-ANDRA scientific partnership (ISODIAR project, 2007-2009). A. Genna (BRGM, France), F. J. Pearson (GWG, USA) and O. Leupin (NAGRA, Switzerland) are acknowledged for their contribution and editorial support. The Associate Editor, Dr. Sydney Hemming, and three anonymous referees are thanked for their constructive comments and their significant improvements to the manuscript. 


\section{References}

Ader M., Javoy M. (1998) Early diagenesis in a sulphate-reducing environment: an isotopic study in lower Jurassic of the Paris Basin. C. R. A. sci. - serie IIA - Earth and planetary science 327, 803-809.

ANDRA (1996) Chap. II renseignements d'ordre géologique et géophysique disponibles quant au caractère favourable des formations à étudier. ANDRA report - ANDRA/DIR/96/1138. Paris, France.

ANDRA (2005) Evaluation de la faisabilité du stockage géologique en formation argileuse, Dossier 2005. Collection Les Rapports.

Appelo C.A.J., Vinsot A., Mettler S., Wechner S. (2008) Obtaining the porewater composition of a clay rock by modeling the in- and out-diffusion of anions and cations from an in-situ experiment. J. Contam. Hydrol. 101, 67-76.

Baker P.A., Bloomer S. H., (1988) The origin of celestite in deep-sea carbonate sediments. Geochim. Cosmochim. Acta 52, 335-339.

Blanc P., Gaucher E.C. (2003) Minéralogie du Callovo-Oxfordien en vue d'une modélisation thermodynamique. BRGM Report - BRGM/RP-52040-FR.

Blanc P., Legendre O., Gaucher E.C. (2007) Estimate of clay minerals amounts from XRD pattern modeling: The Arquant model. Phys. Chem. Earth 32, 135-144.

Böttcher M.E., Lepland A. (2000) Biogeochemistry of sulfur in a sediment core from the west-central Baltic Sea: Evidence from stable isotopes and pyrite textures. J. Marine Syst. 25, 299-312.

Bottrell S. H., Moncaster S. J., Tellam J. H., Lloyd J. W., Fisher Q. J., Newton R. J. (2000) Controls on bacterial sulphate reduction in a dual porosity aquifer system: the Lincolnshire Limestone aquifer, England. Chem. Geol. 169, 461-470.

Brigaud B., Durlet C., Deconinck J-F., Vincent B., Thierry J., Trouiller A. (2010). The origin and timing of multiphase cementation in carbonates: Impact of regional scale geodynamic events on the Middle Jurassic Limestones diagenesis (Paris Basin, France). Sedimentary Geol. 222, Issues 3-4, 161-180.

Brock T. D., Madigan M. T., Martinko J. M., Parker J. (1994) Biology of microorganisms. PrenticeHall, Eagle-wood Cliffs, NJ, 909p.

Brunner B., Bernasconi S.M. (2005) A revised isotope fractionation model for dissmimilatory sulphate reduction in sulphate reducing bacteria. Geochim. Cosmochim. Acta 69, 4759-4771.

Brunner B., Bernasconi S.M., Kleikemper J., Schroth M.H. (2005) A model for oxygen and sulfur isotope fractionation in sulfate during bacterial sulfate reduction processes. Geoch. Cosmochim. Acta 69, 4773-4785.

Buschaert S. (2001) Origine, âge et processus physico-chimiques des circulations de fluides dans les fractures: exemple de socle sous couverture (Vienne) et de formations riches en argiles (Gard, Est). PhD thesis, University of Nancy I, $n^{\circ}$ Gdr Forpro 2001/28Th, published by Andra in 03/2002, n²14-6. 
Buschaert S., Fourcade S., Cathelineau M., Deloule E., Martineau F., Ayt Ougougdal M., Trouiller A. (2004) Widespread cementation induced by inflow of continental water in the eastern part of the Paris basin: $\mathrm{O}$ and $\mathrm{C}$ isotopic study of carbonate cements. Appl. Geochem. 19, 1201-1215.

Canfield D.E. (2001) Biogeochemistry of sulphur isotopes. In Stable Isotope Geochemistry, Reviews in Mineralogy Vol. 43. (Eds J.W. Valley and D.R. Cole) Mineralogical Society of America.

Carpentier C., Breton G., Huault V., Lathuiliere B. (2006) Decapods crustaceans from the Kimmeridgian of Bure (Lorraine, France). Geobios 39, 617-629.

Casanova J., Negrel Ph., Aranyossy J.F., Bruhlet J. (1999) Callovo-Oxfordian argillites (Meuse, France): Isotope Geochemistry (O, C, Sr). In 3rd International Symposium on Applied Isotope Geochemistry, September 21-25, 1999, Orléans, France, 127-128.

Casanova J., Negrel P., Brulhet J. (2001) Tracing oxic intrusions in Jurassic deposits from the Bure site, Meuse (France). In WRI-10 - International Symposium on Water Rock Interaction 10th Villasimius - Italy - 10-15/06/2001, 2, 1505-1508.

Cassagnabère A. (2001) Laboratoire de Recherche Souterrain de Meuse/Haute-Marne - Analyses minéralogiques et géochimiques du forage EST205. Rapport de mesure final B RP0ERM 00030/A.

Claret F., Sakharov B. A., Drits V. A., Velde B., Meunier A., Griffault L., Lanson B. (2004) Clay minerals in the Meuse - Haute Marne underground laboratory (France): Possible influence of organic matter on clay mineral evolution. Clays and Clay Miner. 52, 515-532.

Clauer N., Fourcade S., Cathelineau M., Girard J.P., Vincent B. (2007) A review of studies on the diagenetic evolution of the Dogger-to-Tithonian sedimentary sequence in the eastern Paris Basin - Impact on the physical and chemical rock properties. Mém. Soc. Géol. France 178, 5971.

Claypool G.E., Holser W.T., Kaplan I.R., Sakai H., Zak I. (1980) The age curve of sulfur and oxygen isotopes in marine sulfate and their mutual interpretation. Chem. Geol. 28, 199-260.

Clayton R.N., Mayeda T.K. (1963) The use of bromine pentafluoride in the extraction of oxygen from oxides and silicates for isotopic analysis. Geochim. Cosmochim. Acta 27, 43-52.

Delay J., Distinguin M., Dewonck S. (2007) Characterization of a clay-rich rock through development and installation of specific hydrogeological and diffusion test equipment in deep boreholes. Phys. Chem. Earth 32, 393-407.

Descostes M., Blin V., Bazer-Bachi F., Meier P., Grenut B., Radwan J., Schlegel M. L., Buschaert S., Coelho D., Tevissen E. (2008) Diffusion of anionic species in Callovo-Oxfordian argillites and Oxfordian limestones (Meuse/Haute-Marne, France). Appl. Geochem. 23, 655-677.

Disnar J. R., Le Strat P., Farjanel G., Fikri A. (1996) Sédimentation de la matière organique dans le nord-est du Bassin de Paris: conséquences sur le dépôt des argilites carbonées du Toarcien inférieur. Chem. Geol. 131, 15-35.

Esteban L., Bouchez J.L., Trouiller A. (2006) The Callovo-Oxfordian argillites from the eastern Paris Basin: Magnetic data and petrofabrics. C. R. Geosci. 338, 867-881.

Fauconnier D. (1995) Jurassic Palynology from a borehole in the champagne area, France correlation of the lower Callovian-middle Oxfordian using sequence stratigraphy. Rev. Palaeobotany and palynology 87, 15-26. 
Ferry S., Pellenard P., Collin P.Y., Thierry J., Marchand D., Deconinck J.F., Robin C., Carpentier C., Durlet C., Curial A. (2007) Synthesis of recent stratigraphic data on Bathonian to Oxfordian deposits of the eastern Paris basin. Mém. Soc. Geol. France 178, 37-57.

Fredrickson J. K., McKinley J. P., Bjornstad B. N., Long P. E., Ringelberg D. B., White D. C., Krumholz L. R., Suflita J. M., Colwell F. S., Lehman R. M., Phelps T. J., Onstott T. C. (1997) Pore-size constraints on the activity and survival of subsurface bacteria in a late Cretaceous shale-sandstone sequence, northwestern New Mexico. Geomicrobio. J. 14, 183-202.

Gaucher E., Robelin C., Matray J.M., Negrel G., Gros Y., Heitz J.F., Vinsot A., Rebours H., Cassagnabere A., Bouchet A. (2004) ANDRA underground research laboratory: interpretation of the mineralogical and geochemical data acquired in the Callovian-Oxfordian formation by investigative drilling. Phys. Chem. Earth A/B/C 29, 55-77.

Gaucher E.C., Blanc P., Bardot F., Braibant G., Buschaert S., Crouzet C., Gautier A., Girard J.P., Jacquot E., Lassin A. (2006) Modelling the porewater chemistry of the Callovian-Oxfordian formation at a regional scale. C. R. Geosci. 338, 917-930.

Gaucher E. C., Tournassat C., Pearson F. J., Blanc P., Crouzet C., Lerouge C., Altmann S. (2009) A robust model for pore-water chemistry of clayrock. Geochim. Cosmochim. Acta 73, 64706487.

Gaucher E.C., Lerouge C., Blanc P., Tournassat C. (2007) Caractérisation géochimique des forages PAC et nouvelles modélisations THERMOAR. BRGM Reports BRGM/RP-54416-FR.

Giannesini S. (2006) Géochimie isotopique couplée des eaux des formations argileuses et calcaires du site ANDRA de Meuse/Haute-Marne. PhD Université Paul Cézanne Aix-Marseille III.

Girard J-P., Fléhoc C., Gaucher E.C (2005) Stable-isotope composition of $\mathrm{CO}_{2}$ outgassed from cores of argillites: a simple method to constrain $\delta^{18} \mathrm{O}$ of porewater and $\delta^{13} \mathrm{C}$ of dissolved carbon in mudrocks. Appl. Geochem. 20, 713-725.

Goldhaber M.B., Kaplan I.R. (1974) The sulfur cycle. In: Goldberg (ed.). The Sea. Wiley Interscience, New York, 5, 569-655.

Guillocheau F. (1991) Mise en évidence de grands cycles transgression-régression d'origine tectonique dans les sédiments mésozoïques du Bassin de Paris. C.R. Acad. Sci. Paris 312, 1587-1593.

Guillocheau F., Robin C., Allemand P., Bourquin S., Brault N. (2000) Meso-cenozoic geodynamic evolution of the Paris Basin : 3D stratigraphic constraints. Geodinamica Acta 13, 189-246.

Hautevelle Y., Michels R., Malartre F., Elie M., Trouiller A. (2007) Tracing of variabilities within a geological barrier by molecular organic geochemistry. Case of the Callovo-Oxfordian sedimentary series in the East of the Paris Basin (France). Applied Geochem. 22, 736-759.

Hey M. H. (1954) A new review of the chlorites. Mineral. Mag. 30, 277-292.

Hoareau G, Monnin C., Odonne F. (2010) A study of celestine equilibrium in marine sediments using the entire ODP/IODP porewater data base. Geochim. Cosmochim. Acta 74, 3925-3937. 
Hudson J.D., Coleman M.L., Barreiro B.A., Hollingworth N.T.J. (2001) Septarian concretions from the Oxford Clay (Jurassic, England, UK): involvement of original marine and multiple external pore fluids. Sedimentology 48, 507-531.

Jones C. E., Jenkyns H. C. (2001) Seawater Strontium Isotopes, Oceanic Anoxic Events, and Seafloor Hydrothermal Activity in the Jurassic and Cretaceous. Am. J. Sci. 312, 112-149.

Kampschulte A., Strauss H. (2004) The sulfur isotopic evolution of Phanerozoic seawater based on the analysis of structurally substituted sulfate in carbonates. Chem. Geol. 204, 255-286.

Kim S.-T., O'Neil J.R. (1997) Equilibrium and nonequilibrium oxygen isotope effects in synthetic carbonates. Geochim. Cosmochim. Acta 61, 3461-3475.

Kita I., Taguchi S., Matsubaya O. (1985) Oxygen isotope fractionation between amorphous silica and water at $34-90^{\circ} \mathrm{C}$. Nature $314,83-84$.

Knauth J.P., Epstein S. (1976) Hydrogen and oxygen isotope ratios in nodular and bedded cherts. Geochim. Cosmochim. Acta 40, 1095-1108.

Koepnick R.B., Denison R.E., Burke W.H., Hetherington E.A., Dahl D.A. (1990) Construction of the Triassic and Jurassic portion of the Phanerozoic curve of seawater $87 \mathrm{Sr} / 86 \mathrm{Sr}$. Chem. Geol. 80, 327-349.

Lamiraux C., Mascle A., 1998. Petroleum exploration and production in France. Oil Gas Sci. Technol. - Rev. IFP. 16, 109-117.

Landais P., Elie M. (1999) Utilisation de la géochimie organique pour la détermination du paléoenvironnement et de la paléothermicité dans le Callovo-Oxfordien du site de l'Est de la France. Actes des Journées Scientifiques CNRS/ANDRA, EDP Sciences Ed., Paris

Lerouge C., Gaucher E. C., Tournassat C., Negrel P., Crouzet C., Guerrot C., Vinsot A., Buschaert S. (2010) Strontium distribution and origins in a natural clayey formation (Callovian-Oxfordian, Paris Basin, France): a new sequential extraction procedure. Geoch. Cosmochim. Acta 74, 2926-2942.

Lerouge C., Claret F., Denecke M.A., Wille G., Falkenberg G., Ramboz C., Beny C., Giffaut E., Schäfer T., Gaucher E.C., Tournassat C. (2010) Comparative EPMA and I-XRF methods for mapping micro-scale distribution of iodine in biocarbonates of the Callovian-Oxfordian clayey formation at Bure, Eastern part of the Paris Basin. Physics and Chemistry of the Earth 35, 271277.

Le Nindre Y.M., Donsimoni M., Cubizolles J., Vaslet D. (1995) Zone d'étude Haute marne forage 103. Etude pétro-sédimentaire et stratigraphqiue des échantillons de carottes. BRGM reports BRGM/RN-02297-FR

McCrea J.M. (1950) On the isotope chemistry of carbonates and a palaeotemperature scale. J. Chem. Phys 18, 849-857.

Magniez F., Médioni R, Mégnien C., Amedro F., Destombes P., Fauvel P.J., Manivit J., Robaszynski F., Sornay J. (1980) Crétacé inférieur. In : Mégnien C., Mégnien F. (Eds).Synthèse géologique du Bassin de Paris. Volume I - Stratigraphie et paléogéographie. BRGM 101, 446p.

Matsuhisa Y., Goldsmith J.R., Clayton R.N. (1979) Oxygen isotope fractionation in the system quartz-albite-anorthite-water. Geochim Cosmochim Acta 43, 1131-1140. 
Michels R. (2001) Site Meuse/Haute-Marne - Caractérisation microscopique des hétérogénéités de distribution de la matière organique dans les argiles du Callovo-Oxfordien. ANDRA reports - D RP 0CRE 01-003.

Morad S. (1988) Diagenesis of titaniferous minerals in Jurassic sandstones from the Norwegian Sea. Sed. Geol. 57, 17-40.

Mosser-Ruck R., Pironon J., Cathelineau M., Trouiller A. (1999) Simulation expérimentale de la transformation smectite-illite : contribution de l'analyse des solutions à l'équilibre à l'interprétation des mécanismes de transformation. ASF : 7ième Congrès Français de Sédimentologie. 15-17 novembre 1999. Nancy.

Mozley P.S. (1989) Relation between depositional environment and the elemental composition of early diagenetic siderite. Geology 17, 704-706.

Ohmoto H., Kaiser C.J., Geers K.A. (1990) systematics of sulphur isotopes in recent marine sediments and ancient sediment-hosted basemetal deposits. In Stable Isotopes and fluid processes in Mineralization. Vol. 23 (ed. H.K. Herbert and S.E. Ho), pp. 70-120, Geology Department \& University extension, the University of Western Australia.

Pellenard P., Deconninck J.F., Marchand D., Thierry J., Fortwrengler D., Vigneron G. (1999) Contrôle géodynamique de la sédimentation argileuse du Callovien-Oxfordien moyen dans l'est du Bassin de Paris : influence eustatique et volcanique. C.R. Acad. Sci. Série IIA 328, 807-813.

Pellenard P., Deconinck J.F. (2006) Mineralogical variability of Callovo-Oxfordian clays from the Paris Basin and the Subalpine Basin. C. R. Geosci. 338, 854-866.

Pin C., Bassin C (1992) Evaluation of a strontium specific extraction chromatographic method for isotopic analysis in geological materials. Anal. Chim. Acta 269, 249-255.

Prinzhofer A., Girard J. P., Buschaert S., Huiban Y., Noirez S. (2009) Chemical and isotopic characterization of hydrocarbon gas traces in porewater of very low permeability rocks: The example of the Callovo-Oxfordian argillites of the eastern part of the Paris Basin. Chem. Geol. 260, 269-277.

Rees C.E. (1973) Steady-state model for sulphur isotope fractionation in bacterial reduction processes. Geochim. Cosmochim. Acta 37, 1141-1162.

Rickard D.T. (1975) Kinetics and mechanism of pyrite formation at low temperatures. Amer. J. Sci. 275, 636-652.

Rickard D.T., Luther G. W., 2007. Chemistry of iron sulfides. Chemical reviews 107, 514-562.

Rosenbaum M.S. (1976) effect of compaction on the pore fluid chemistry of montmorillonite. Clays and Clay minerals 24, 118-121.

Rosenbaum J., Sheppard S.M. (1986) An isotopic study of siderites, dolomites and ankerites at high temperatures. Geochim. Cosmochim. Acta 50, 1147-1150.

Rousset D. (2002) Etude de la fraction argileuse de séquences sédimetaires de la Meuse et du gard. Reconstitution de l'histoire diagénétique et des caractéristiques physico-chimiques des cibles. Aspects minéralogiques, géochimiques et isotopiques. PhD thesis, University of Strasbourg. 
Rousset D., Clauer N. (2003) Discrete clay diagenesis in a very low-permeable sequence constrained by an isotopic (K-Ar and Rb-Sr) study. Contrib. Mineral. Petrol. 145, 182-198.

Sammartino S., Bouchet A., Prêt D., Parneix J. -C., Tevissen E. (2003) Spatial distribution of porosity and minerals in clay rocks from the Callovo-Oxfordian formation (Meuse/Haute-Marne, Eastern France)-implications on ionic species diffusion and rock sorption capability.

Appl. Clay Sci. 23, 157-166.

Schwarz H. E, Burnie S. W. (1973) Influence of sedimentary environments on sulfur isotope ratios in clastic rocks: A review. Min. Dep, 8, 264-277.

Sweeney R.E., Kaplan I.R. (1973) Pyrite framboïd formation: laboratory synthesis and marine sediments. Econ. Geol. 68, 618-643.

Thierry J., Cariou E., Dubois P., Fily G., Gabilly J., Laurin B., Le Roux J., Lorenz J., Rioult M., Yapaudjian L. (1980) Jurassique Moyen. In: Mégnien C., Mégnien F. (Eds).Synthèse géologique du Bassin de Paris. Volume I - Stratigraphie et paléogéographie. BRGM 101, 125193.

Tournassat C., Lerouge C., Blanc P., Brendle J., Greneche J. M., Touzelet S., Gaucher E. C. (2008) Cation exchanged $\mathrm{Fe}(\mathrm{II})$ and $\mathrm{Sr}$ compared to other divalent cations $(\mathrm{Ca}, \mathrm{Mg}$ ) in the bure Callovian-Oxfordian formation: Implications for porewater composition modelling. Applied Geochem. 23, 641-654.

Vaslet D., Giot D., Le Nindre Y.M., Mossmann J.R. (1995) Zone d'étude Meuse. Forage MSE101. Etude pétro-sédimentaire, granulométrique et stratigraphique des échantillons de carottes. UNIVERSITE DE BOURGOGNE; ANTEA STO, Commanditaire. - BRGM (Orléans), BRGM/RN02088-FR.

Vincent B. (2001) Sédimentologie et géochimie de la diagenèse des carbonates. Application au Malm de la bordure est du Bassin de Paris. PhD Thesis.

Vincent B., Emmanuel L., Houel P., Loreau J.-P. (2007) Geodynamic control on carbonate diagenesis : petrographic and isotopic investigation of the Upper Jurassic formation of the Paris Basin (France). Sedimentary Geol. 197, 267-289.

Vinsot A., Mettler S., Wechner S. (2008) In situ characterization of the Callovo-Oxfordian pore water composition. Phys. Chem. Earth A/B/C 33, S75-S86.

Veizer J., Mackenzie F. T., 2004. Evolution of sedimentary rocks, chapter 7.15. In Treatise on Geochemistry Vol. 7 (eds. F. T. Mackenzie (volume), H. D. Holland and K. K. Turekian). Elsevier, Amsterdam, 369-407.

Wang Q., Morse J.W. (1996) Pyrite formation under conditions approximating those in anoxic sediments: I. Mechanism and morphology. Mar. Chem. 52, 99-121.

Wortmann U.G., Bernasconi S.M., Boettcher M.E. (2001) Hypersulfidic deep biosphere indicates extreme sulphur isotope fractionation during single-step microbial sulphate reduction. Geology 29, 647-650.

Yven B., Sammartino S., Géraud Y., Homand F., Villiéras F. (2007) Mineralogy, Texture and Porosity of Callovo-Oxfordian Argillites of the Meuse/Haute-Marne Region (eastern Paris Basin). Mém. Soc. Geol. France 178, 73-90. 
Table 1 : EPMA analyses of different generations of carbonates in limestone and claystone samples of the Cox unit. Chemical composition is firstly given in weight \% of oxides and secondly as a structural formula calculated on the basis of 3 oxygen atoms.

\begin{tabular}{|c|c|c|c|c|c|c|c|c|c|c|}
\hline & $\mathbf{C a O}$ & FeO & MgO & MnO & SrO & Total & $\mathrm{Ca}$ & $\mathrm{Fe}$ & $\mathrm{Mg}$ \\
\hline & & \multicolumn{6}{|c|}{ Oxides (in wt \%) } & \multicolumn{3}{|c|}{ FS on the basis of 3 Ox. } \\
\hline \multicolumn{11}{|c|}{ LIMESTONE SAMPLES } \\
\hline \multicolumn{5}{|c|}{ Bioclasts - Bure 8} & \multicolumn{3}{|l|}{$\mathrm{SO}_{3}$} & & & \\
\hline \multirow{2}{*}{$\begin{array}{l}\text { Terebratula } \\
n=92\end{array}$} & \multirow{2}{*}{$\begin{array}{l}\text { average } \\
\text { mean variation }\end{array}$} & 58,94 & 0,12 & 0,77 & 0,40 & 0,16 & 60,39 & 0,966 & 0,002 & 0,017 \\
\hline & & 1,19 & 0,11 & 0,23 & 0,11 & 0,02 & 1,17 & 0,008 & 0,001 & 0,005 \\
\hline \multirow{2}{*}{$\begin{array}{l}\text { Rhynchonella } \\
\mathrm{n}=85\end{array}$} & \multirow{2}{*}{$\begin{array}{l}\text { average } \\
\text { mean variation }\end{array}$} & 57,90 & 0,12 & 0,35 & 0,20 & 0,08 & 58,65 & 0,982 & 0,002 & 0,008 \\
\hline & & 1,69 & 0,10 & 0,19 & 0,14 & 0,02 & 1,52 & 0,010 & 0,001 & 0,004 \\
\hline \multirow{2}{*}{$\begin{array}{l}\text { Bivalve } \\
\mathrm{n}=214\end{array}$} & \multirow{2}{*}{$\begin{array}{l}\text { average } \\
\text { mean variation }\end{array}$} & 59,15 & 1,39 & 0,56 & 0,22 & 0,07 & 61,39 & 0,962 & 0,018 & 0,013 \\
\hline & & 1,83 & 0,35 & 0,22 & 0,09 & 0,02 & 1,83 & 0,009 & 0,004 & 0,005 \\
\hline \multicolumn{11}{|l|}{ Micritic calcite } \\
\hline \multirow{2}{*}{$\begin{array}{l}\text { EST5433 } \\
n=3\end{array}$} & \multirow{2}{*}{$\begin{array}{l}\text { average } \\
\text { mean variation }\end{array}$} & 52,25 & 0,13 & 0,74 & 0,01 & - & 55,49 & 0,979 & 0,002 & 0,019 \\
\hline & & 2,04 & 0,09 & 0,04 & 0,01 & - & 0,64 & 0,001 & 0,001 & 0,002 \\
\hline \multirow{2}{*}{$\begin{array}{l}\text { EST21400 } \\
n=15\end{array}$} & \multirow{2}{*}{$\begin{array}{l}\text { average } \\
\text { mean variation }\end{array}$} & 56,67 & 0,21 & 0,66 & 0,03 & 0,05 & 59,21 & 0,980 & 0,003 & 0,016 \\
\hline & & 1,60 & 0,20 & 0,34 & 0,02 & 0,04 & 1,70 & 0,010 & 0,003 & 0,008 \\
\hline \multirow{2}{*}{$\begin{array}{l}\text { Bure } 2 \\
n=11\end{array}$} & \multirow{2}{*}{$\begin{array}{l}\text { average } \\
\text { mean variation }\end{array}$} & 54,13 & 0,22 & 0,70 & 0,03 & 0,04 & 57,73 & 0,978 & 0,003 & 0,018 \\
\hline & & 1,58 & 0,11 & 0,10 & 0,02 & 0,02 & 1,36 & 0,004 & 0,002 & 0,002 \\
\hline \multicolumn{11}{|c|}{ Limpid microspar calcite } \\
\hline \multirow{2}{*}{$\begin{array}{l}\text { EST5485 } \\
n=2\end{array}$} & average & 54,31 & 0,18 & 0,60 & 0,02 & 0,02 & 56,18 & 0,982 & 0,003 & 0,015 \\
\hline & mean variation & 0,10 & 0,06 & 0,02 & 0,02 & 0,02 & 0,21 & 0,001 & 0,001 & 0,000 \\
\hline Calcite in in & of bioclasts an & d vein & & & & & & & & \\
\hline Bure 3 & average & 57,43 & 0,78 & 0,69 & 0,08 & 0,00 & 59,19 & 0,972 & 0,010 & 0,016 \\
\hline $\mathrm{n}=51$ & mean variation & 1,26 & 0,24 & 0,15 & 0,02 & 0,00 & 1,19 & 0,005 & 0,003 & 0,004 \\
\hline K108 & & 58,32 & 0,56 & 0,51 & 0,00 & - & 60,00 & 0,981 & 0,007 & 0,012 \\
\hline EST5485 & average & 51,05 & 0,72 & 0,64 & 0,07 & - & 56,55 & 0,971 & 0,011 & 0,017 \\
\hline $\mathrm{n}=7$ & mean variation & 1,43 & 0,14 & 0,11 & 0,06 & - & 1,15 & 0,817 & 0,064 & 0,085 \\
\hline EST20433 & average & 57,26 & 0,30 & 0,45 & 0,13 & 0,00 & 58,31 & 0,984 & 0,004 & 0,011 \\
\hline $\mathrm{n}=27$ & mean variation & 1,00 & 0,23 & 0,22 & 0,05 & 0,00 & 1,02 & 0,007 & 0,003 & 0,005 \\
\hline Euhedral dc & & & & & & & & & & \\
\hline EST5433 & average & 32,74 & 0,91 & 18,64 & 0,01 & 0,02 & 52,98 & 0,551 & 0,012 & 0,437 \\
\hline$n=9$ & mean variation & 0,65 & 0,17 & 1,20 & 0,02 & 0,02 & 0,99 & 0,263 & 0,053 & 0,673 \\
\hline Dolomit & gs of bioclasts & and cra & cks & & & & & & & \\
\hline Bure 3 & average & 36,55 & 3,05 & 15,79 & 0,13 & 0,00 & 55,89 & 0,599 & 0,039 & 0,360 \\
\hline $\mathrm{n}=45$ & mean variation & 1,42 & 0,67 & 1,20 & 0,02 & 0,00 & 0,53 & 0,029 & 0,008 & 0,025 \\
\hline EST5485 & average & 31,58 & 3,78 & 15,87 & 0,09 & 0,03 & 54,21 & 0,557 & 0,052 & 0,390 \\
\hline $\mathrm{n}=9$ & mean var & 0,45 & 1,00 & 0,48 & 0,07 & 0,05 & 1,14 & 0,225 & 0,394 & 0,339 \\
\hline CLAYSTO & PLES & & & & & & & & & \\
\hline Bioclasts & & & & & & & & & & \\
\hline EST25380 & average & 50,86 & 0,51 & 1,41 & 0,12 & 0,08 & 55,98 & 0,953 & 0,007 & 0,037 \\
\hline$n=8$ & mean variation & 2,93 & 0,21 & 0,29 & 0,06 & 0,04 & 3,19 & 0,010 & 0,003 & 0,008 \\
\hline Micritic calc & & & & & & & & & & \\
\hline EST21439 & average & 55,77 & 0,83 & 0,81 & 0,07 & 0,05 & 59,56 & 0,968 & 0,011 & 0,020 \\
\hline$n=45$ & mean variation & 1,63 & 0,38 & 0,31 & 0,07 & 0,04 & 1,06 & 0,009 & 0,005 & 0,007 \\
\hline EST25380 & average & 50,06 & 0,82 & 1,06 & 0,05 & 0,06 & 56,93 & 0,957 & 0,012 & 0,029 \\
\hline $\mathrm{n}=5$ & mean variation & 5,83 & 0,40 & 0,25 & 0,04 & 0,01 & 5,21 & 0,011 & 0,006 & 0,009 \\
\hline Euhe & & & & & & & & & & \\
\hline EST25687 & & 49,01 & 0,55 & 1,47 & 0,15 & 0,05 & 52,37 & 0,949 & 0,008 & 0,040 \\
\hline
\end{tabular}




\begin{tabular}{|c|c|c|c|c|c|c|c|c|c|c|}
\hline \multicolumn{11}{|c|}{ Limpid microspar calcite } \\
\hline \multirow{2}{*}{$\begin{array}{l}\text { EST5474 } \\
\mathrm{n}=5\end{array}$} & average & 56,24 & 0,81 & 0,84 & 0,04 & 0,04 & 59,32 & 0,968 & 0,011 & 0,020 \\
\hline & mean variation & 0,68 & 0,18 & 0,18 & 0,03 & 0,05 & 0,66 & 0,005 & 0,002 & 0,004 \\
\hline \multirow{2}{*}{$\begin{array}{l}\text { EST5554 } \\
n=3\end{array}$} & average & 56,02 & 1,11 & 0,67 & 0,05 & 0,06 & 59,09 & 0,968 & 0,015 & 0,016 \\
\hline & mean variation & 1,98 & 0,18 & 0,18 & 0,04 & 0,03 & 1,69 & 0,006 & 0,002 & 0,004 \\
\hline \multirow{2}{*}{$\begin{array}{l}\text { EST5724 } \\
n=7\end{array}$} & average & 44,41 & 1,70 & 0,90 & 0,12 & - & 50,21 & 0,943 & 0,028 & 0,027 \\
\hline & mean variation & 0,31 & 0,51 & 0,19 & 0,07 & - & 8,70 & 0,127 & 0,008 & 0,006 \\
\hline \multicolumn{11}{|c|}{ Calcite in core of siderite } \\
\hline \multirow{2}{*}{$\begin{array}{l}\text { EST25687 } \\
n=3\end{array}$} & & 48,99 & 5,49 & 1,08 & 0,14 & 0,02 & 57,84 & 0,892 & 0,078 & 0,027 \\
\hline & & 1,48 & 0,96 & 0,12 & 0,04 & 0,01 & 1,02 & 0,016 & 0,015 & 0,003 \\
\hline \multicolumn{11}{|c|}{ Calcite veinlets in celestite } \\
\hline \multirow{2}{*}{$\begin{array}{l}\text { EST20714 } \\
n=2\end{array}$} & average & 50,71 & 1,36 & 0,46 & 0,11 & 0,54 & 54,41 & 0,961 & 0,020 & 0,012 \\
\hline & mean variation & 0,85 & 0,10 & 0,00 & 0,02 & 0,06 & 1,02 & 0,00 & 0,00 & 0,00 \\
\hline \multicolumn{11}{|c|}{ Euhedral dolomite } \\
\hline \multicolumn{2}{|c|}{ core1-EST25380 } & 32,75 & 0,09 & 23,95 & 0,07 & - & 57,63 & 0,495 & 0,001 & 0,503 \\
\hline & 30,82 & 0,16 & 22,24 & 0,09 & - & 54,21 & 0,497 & 0,002 & 0,499 \\
\hline \multirow{2}{*}{\multicolumn{2}{|c|}{$\begin{array}{l}\text { core2-EST25380 } \\
\text { rim2-EST25380 }\end{array}$}} & 31,07 & 0,04 & 22,90 & 0,13 & 0,47 & 55,23 & 0,491 & 0,000 & 0,503 \\
\hline & & 32,96 & 0,08 & 23,60 & 0,10 & 0,57 & 58,06 & 0,497 & 0,001 & 0,496 \\
\hline \multicolumn{2}{|l|}{ rim-EST25380 } & 31,72 & 0,21 & 22,48 & 0,02 & 0,41 & 55,38 & 0,500 & 0,003 & 0,493 \\
\hline \multirow{2}{*}{$\begin{array}{l}\text { EST25380 } \\
n=7\end{array}$} & average & 31,46 & 0,20 & 22,37 & 0,14 & 0,21 & 55,34 & 0,500 & 0,003 & 0,494 \\
\hline & mean variation & 0,87 & 0,13 & 0,99 & 0,09 & 0,24 & 1,44 & 0,006 & 0,002 & 0,007 \\
\hline \multicolumn{2}{|l|}{ core-EST25687 } & 30,49 & 0,88 & 21,08 & 0,07 & 0,03 & 55,15 & 0,503 & 0,011 & 0,484 \\
\hline \multicolumn{2}{|l|}{ rim-EST25687 } & 32,35 & 1,61 & 21,76 & 0,03 & - & 57,75 & 0,506 & 0,020 & 0,474 \\
\hline \multicolumn{2}{|l|}{ core-EST21439 } & 29,70 & 0,29 & 22,88 & 0,38 & - & 56,79 & 0,478 & 0,004 & 0,513 \\
\hline \multicolumn{2}{|l|}{ rim-EST21439 } & 32,85 & 6,06 & 16,56 & 0,04 & 0,03 & 56,46 & 0,542 & 0,078 & 0,380 \\
\hline \multirow{2}{*}{$\begin{array}{l}\text { EST21439 } \\
n=14\end{array}$} & average & 30,99 & 0,74 & 23,85 & 0,12 & 0,02 & 57,38 & 0,478 & 0,009 & 0,511 \\
\hline & mean variation & & 0,78 & 1,89 & & 0,02 & 2,00 & 0,011 & 0,010 & 0,019 \\
\hline \multicolumn{2}{|l|}{ core-EST12436 } & 32,33 & 0,20 & 23,29 & 0,29 & 0,00 & 58,71 & 0,496 & 0,002 & 0,498 \\
\hline \multicolumn{2}{|l|}{ rim-EST12436 } & 33,66 & 2,99 & 15,52 & 0,12 & 0,00 & 55,21 & 0,584 & 0,040 & 0,374 \\
\hline \multicolumn{11}{|c|}{ Siderite-EST25687 } \\
\hline \multirow{2}{*}{$\begin{array}{l}\text { Siderite-ES1256 } \\
\text { EST25687 } \\
n=7\end{array}$} & average & 5,95 & 40,64 & 7,36 & 0,14 & - & 55,77 & 0,124 & 0,661 & 0,212 \\
\hline & mean variation & 0,30 & 1,06 & 0,69 & 0,08 & - & 1,56 & 0,004 & 0,015 & 0,015 \\
\hline
\end{tabular}


Table 2: EPMA analyses of framboidal pyrite disseminated in the matrix of rock from the $\mathrm{C} 2 \mathrm{~b}$ and C2c sub-units.

\begin{tabular}{|c|c|c|c|c|c|c|c|c|c|c|c|c|}
\hline & \multicolumn{4}{|c|}{ C2b1 (133 analyses) } & \multicolumn{4}{|c|}{ C2b2 (55 analyses) } & \multicolumn{4}{|c|}{ C2c (77 analyses) } \\
\hline & $\min$ & $\max$ & average & std dev. & $\min$ & $\max$ & average & std dev. & $\min$ & $\max$ & average & std dev. \\
\hline As & 0 & 3460 & 409 & 676 & 0 & 1780 & 236 & 323 & 0 & 690 & 154 & 178 \\
\hline Co & 400 & 1240 & 8 & 166 & 450 & 1130 & 8 & 15 & 360 & 1410 & 8 & 211 \\
\hline $\mathrm{Pb}$ & 0 & 3340 & 1340 & 692 & 0 & 4020 & 1613 & 825 & 0 & 3330 & 1489 & 844 \\
\hline $\mathrm{Cu}$ & 0 & 380 & 106 & 112 & 0 & 980 & 369 & 276 & 0 & 1750 & 261 & 286 \\
\hline $\mathrm{Ni}$ & 0 & 1350 & 382 & 316 & 0 & 1060 & 372 & 306 & 0 & 1970 & 410 & 365 \\
\hline $\mathrm{Zn}$ & 0 & 510 & 61 & 103 & 0 & 550 & 120 & 137 & 0 & 450 & 83 & 117 \\
\hline
\end{tabular}


Table 3. ( $\mathrm{S}, \mathrm{C}, \mathrm{O}, \mathrm{Sr}$ ) isotopic data of diagenetic phases of the Callovian-Oxfordian formation. Sr data from Lerouge et al.(2010a).

Abbreviations: Biotur., pyrite from bioturbations; Diss., framboidal pyrite disseminated in claystone; Cc, calcite; Cc2, late diagenetic calcite; Dol, dolomite/ankerite; Sid, siderite; Chalc1, chalcedony in replacement of bivalve; Chalc2, late chalcedony infilling (postcelestite); Qtz, late euhedral quartz rimming vug.

\begin{tabular}{|c|c|c|c|c|c|c|c|c|c|c|c|}
\hline \multirow[t]{2}{*}{ Samples } & \multirow{2}{*}{$\begin{array}{c}\text { Zngf } \\
\text { (m) }\end{array}$} & \multicolumn{2}{|c|}{ Pyrite } & \multicolumn{3}{|c|}{ Celestite } & \multicolumn{3}{|c|}{ Carbonates } & \multicolumn{2}{|c|}{ Silica } \\
\hline & & $\delta^{34} S$ & & $\begin{array}{l}\delta^{34} S \\
(\mathrm{CDT})\end{array}$ & $\begin{array}{l}\delta^{18} \mathrm{O} \\
\text { (SMOW) }\end{array}$ & $\left.{ }^{8 /} \mathrm{Sr}\right|^{86} \mathrm{sr}$ & & 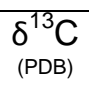 & $\begin{array}{l}\delta^{18} \mathrm{O} \\
\text { (smow) }\end{array}$ & & $\begin{array}{l}\delta^{18} \mathrm{O} \\
\text { (smow) }\end{array}$ \\
\hline EST05433 & -43.5 & & & 22.5 & 20.0 & 0.706945 & Dol & 2.4 & 27.4 & & \\
\hline EST20433 & & & & & & & & & & Qtz & 19.8 \\
\hline EST05485 & -69.9 & & & 27.3 & 21.2 & 0.707373 & & & & & \\
\hline EST05554 & -85.9 & Biotur. & -32.0 & & & & & & & & \\
\hline EST21439 & -93.5 & Diss. & -19.5 & & & & & & & & \\
\hline EST5580 & -96.0 & Biotur. & 7.9 & & & & & & & & \\
\hline EST5583 & -97.6 & Biotur. & 15.4 & & & & & & & & \\
\hline & & Biotur. & -28.7 & & & & & & & & \\
\hline EST5632 & -108.8 & Biotur. & 34.5 & & & & & & & & \\
\hline EST20714 & -109.4 & Diss. & -2.5 & 31.4 & 20.7 & 0.707040 & Cc2 & & 19.6 & Chal2 & 27.7 \\
\hline EST25687 & -109.6 & $\begin{array}{l}\text { Biotur. } \\
\text { Biotur. }\end{array}$ & $\begin{array}{r}12.7 \\
-32.0\end{array}$ & & & & $\begin{array}{l}\text { Cc } \\
\text { Dol } \\
\text { Sid }\end{array}$ & $\begin{array}{l}2.3 \\
1.5 \\
1.2 \\
\end{array}$ & $\begin{array}{l}28.0 \\
27.6 \\
25.9\end{array}$ & & \\
\hline EST5643 & -112.1 & Biotur. & -14.1 & & & & & & & & \\
\hline EST5688 & -123.0 & Biotur. & -22.3 & & & & & & & & \\
\hline Bure1 & -124.0 & & & 25.5 & 19.8 & 0.706935 & & & & Chal1 & 31.7 \\
\hline Bure2 & -124.0 & & & 25.8 & 19.5 & 0.706932 & & & & & \\
\hline Bure3 & $\begin{array}{l}-124.0 \\
\end{array}$ & & & 25.6 & 20.3 & 0.706872 & & & & Chal2 & 26.1 \\
\hline Bure 4 & & & & & & & & & & Chal1 & 31.3 \\
\hline Bure 5 & & & & & & & & & & Chal1 & 31.8 \\
\hline Bure 6 & & & & & & & & & & Chal2 & 27.3 \\
\hline EST26479 & -124.1 & $\begin{array}{l}\text { Biotur. } \\
\text { Biotur. }\end{array}$ & $\begin{array}{r}-33.7 \\
-28.9 \\
\end{array}$ & & & & & & & & \\
\hline EST28099 & -127.3 & Biotur. & -20.2 & & & & & & & & \\
\hline EST05724 & -132.5 & $\begin{array}{l}\text { Biotur. } \\
\text { Biotur. }\end{array}$ & $\begin{array}{l}-38.0 \\
-27.9\end{array}$ & & & & $\begin{array}{l}\text { Cc } \\
\text { Dol } \\
\text { Sid }\end{array}$ & $\begin{array}{c}2.2 \\
1.3 \\
-4.2\end{array}$ & $\begin{array}{l}28.0 \\
27.8 \\
29.5\end{array}$ & & \\
\hline EST25380 & -138.1 & Biotur. & -25.5 & & & & $\begin{array}{l}\text { Cc } \\
\text { Dol } \\
\text { Sid }\end{array}$ & $\begin{array}{r}1.8 \\
1.0 \\
-7.3 \\
\end{array}$ & $\begin{array}{l}27.7 \\
27.4 \\
26.9 \\
\end{array}$ & & \\
\hline EST12436 & -144.0 & $\begin{array}{l}\text { Biotur. } \\
\text { Py -plan }\end{array}$ & $\begin{array}{l}-20.2 \\
74.0\end{array}$ & & & & & & & & \\
\hline
\end{tabular}



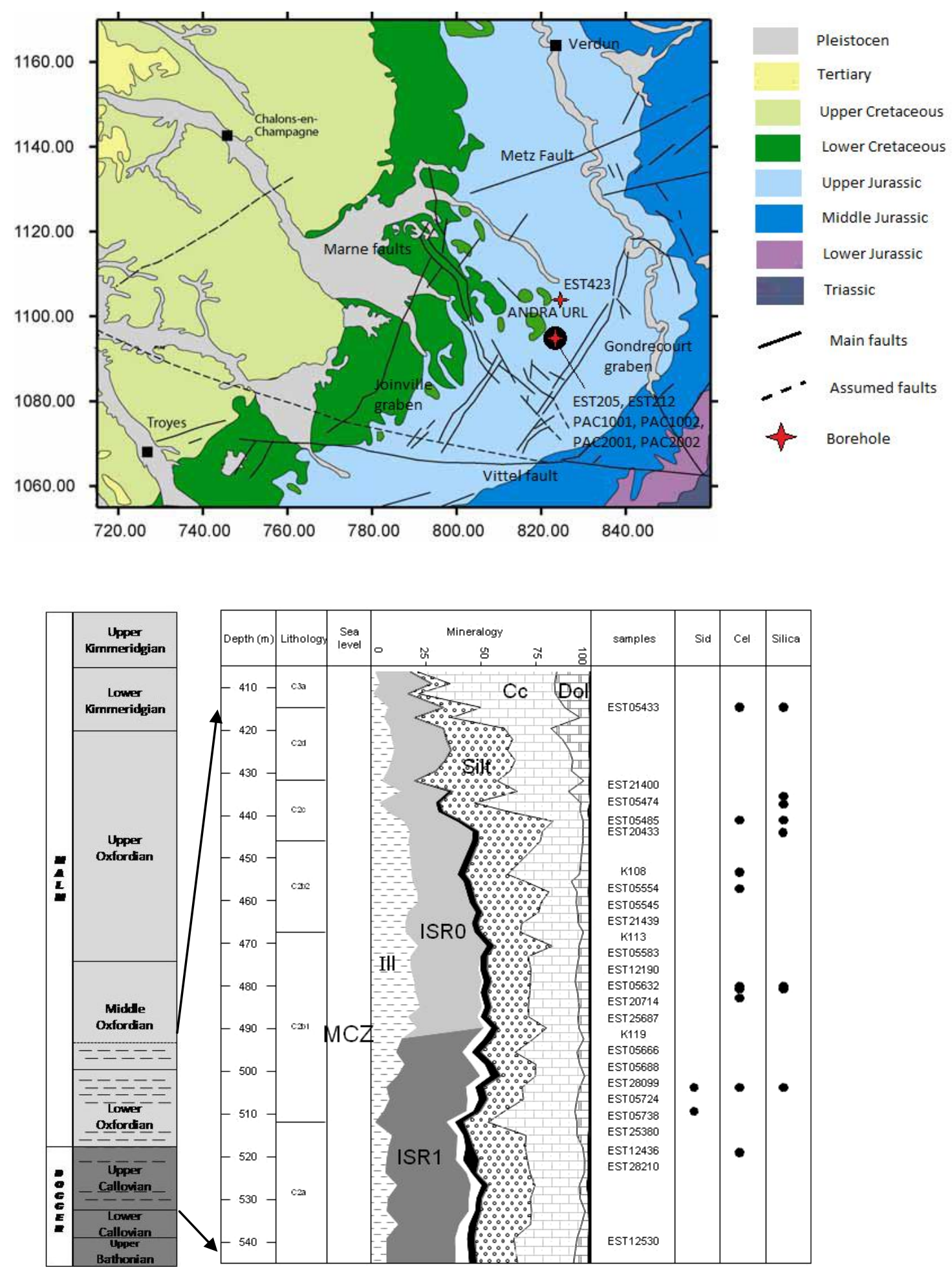

Fig. 1. (a) Location of the Bure Underground Research Laboratory; (b) Lithostratigraphic column at the URL site and position of the Callovian-Oxfordian formation. Schematic distribution of the principal mineralogy (EST205, EST212 boreholes: Ill (illite), ISR $\mathrm{R}_{0}$ and ISR $_{1}$ (illite/ smectite mixed layers), Chl (chlorite), Kln (kaolinite), Silt (quartz + feldspar), Cc (calcite), Dol (dolomite). Location of the samples studied and distribution of accessory diagenetic siderite (Sid), celestite (Cel) and silica. 

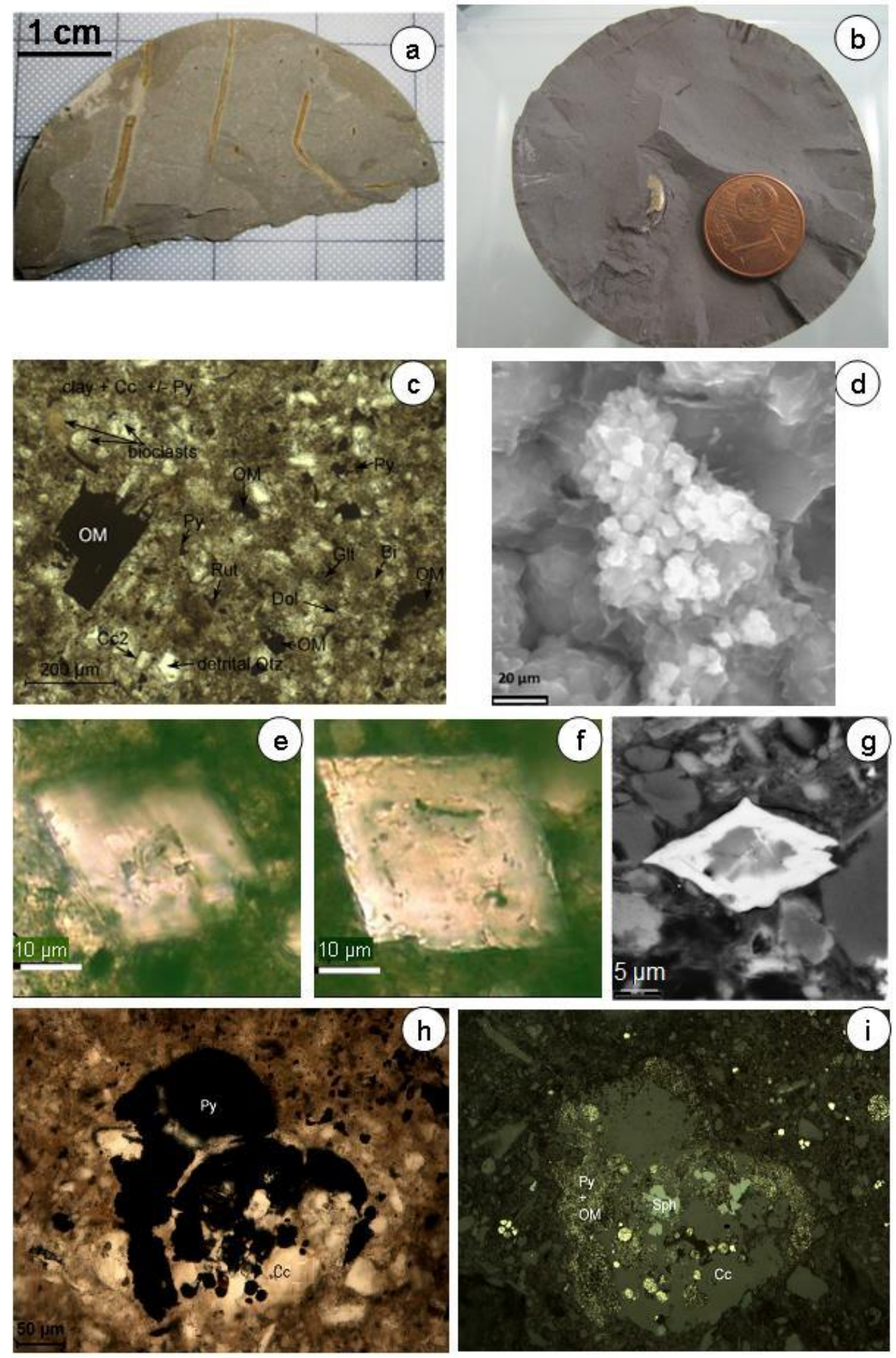

Fig. 2. General characteristics of the claystone samples - (a) Claystone sample K119, presence of bioturbations; (b) Sample EST25380, presence of pyriteous ammonite. Microscopic aspect showing the main mineral phases - (c) General microscopic aspect showing the main mineral phases (sample K119, natural transmitted light); (d) Small framboïd of pyrite with a small coating of calcite (sample K119, BSE image); (e) Euhedral crystal of calcite (sample EST21439, natural transmitted light); (f) Euhedral crystal of dolomite (Do) with a Fe-rich rim and with microinclusions of pyrite (sample EST21439, natural transmitted light); (i) Calcite core surrounded by a growth of siderite (sample EST25380, BSE image). (h)(i) Filling of a small bioclast containing pyrite, limpid calcite and sphalerite (sample K119, natural and polarized transmitted lights). 

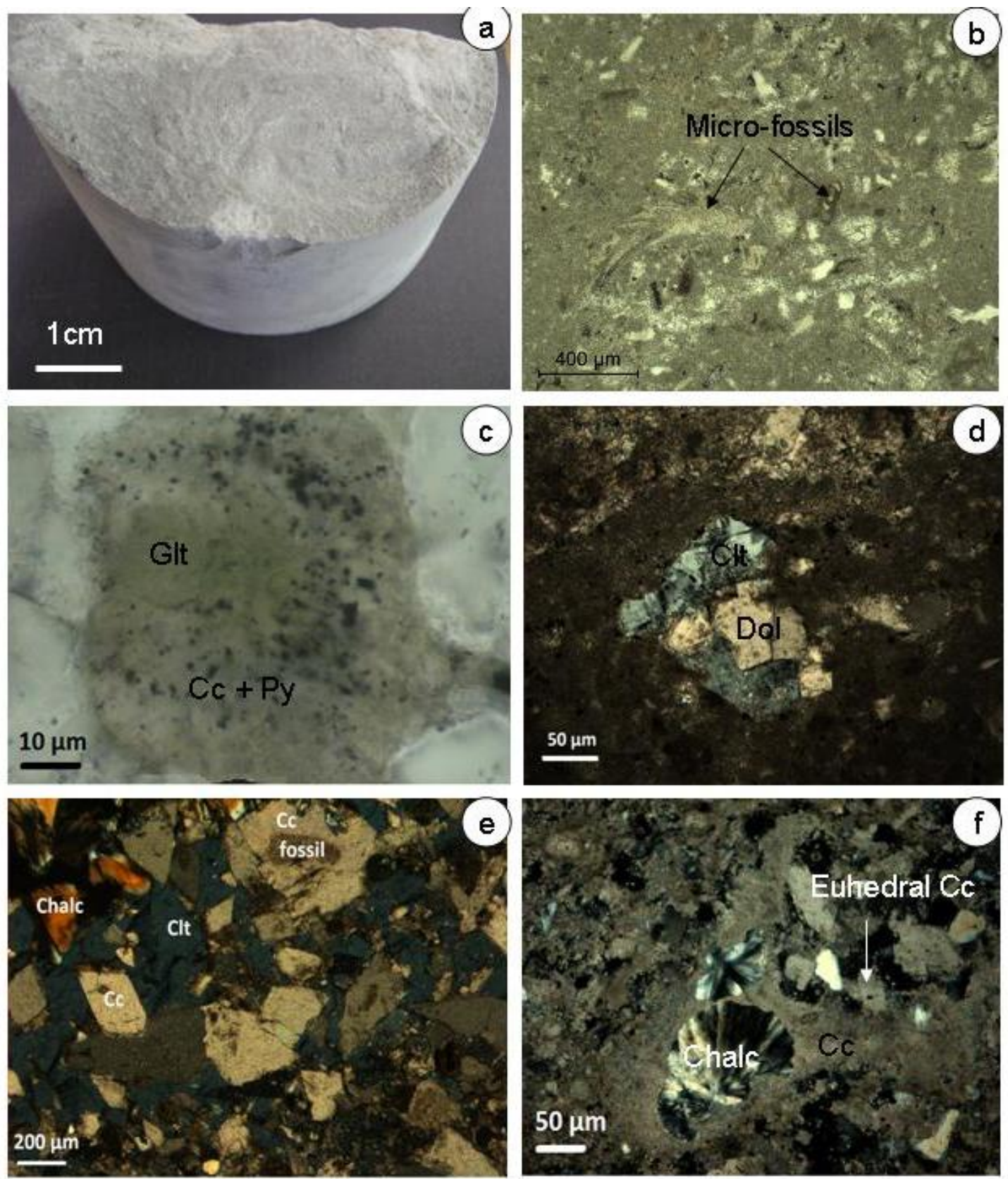

Fig. 3. General characteristics of the limestone samples - (a) homogeneous fine-grained limestone (sample EST5485); (b) micro-fossils in a micritic matrix (sample Bure 3, transmitted natural light); (c) micro-fossil replaced and filled by micritic calcite and pyrite then glauconite (sample K108, transmitted natural light); (d) micritic limestone with small cavities filled by euhedral dolomite and celestite (EST5633, transmitted polarized light); (e) residual porosity in limestone filled by sparitic calcite, celestite and chalcedony (sample Bure 3, polarized transmitted light); (f) silty micritic limestone with cavities rimmed by micritic calcite and filled by chalcedony (EST5485, transmitted polarized light). 

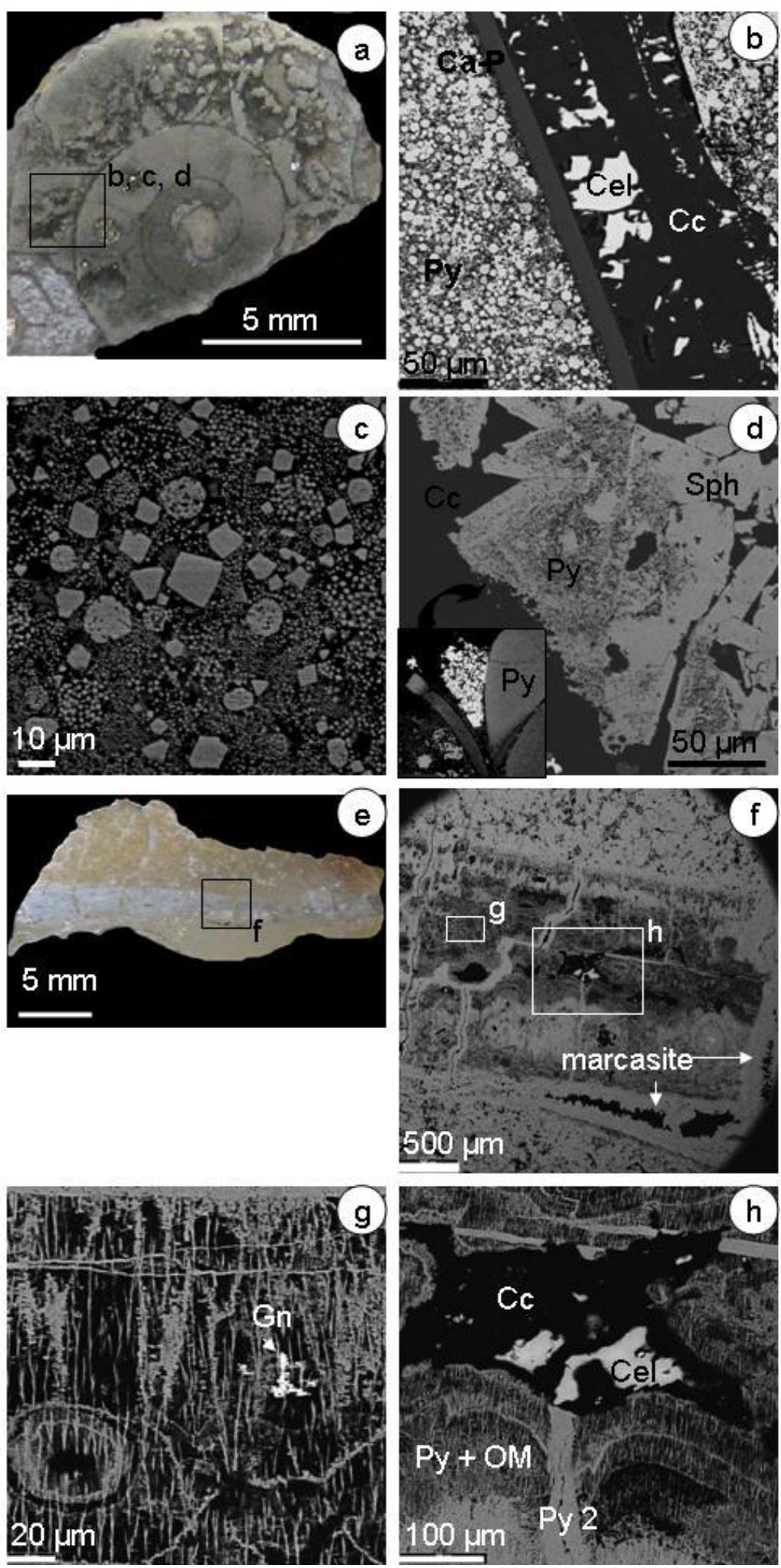

Fig. 4. Pyriteous Ammonite - (a) macroscopic view of a polished section across a pyriteous ammonite; (b) detail of partial replacement and filling of the Ca-phosphorous shell by calcite and celestite, whereas camerae are essentially filled with pyrite; (c) detail of pyrite filling showing framboids and euhedral grains; (d) detail of sphalerite-calcite filling camerae. Pyriteous nodule - (e) macroscopic view of a polished section across a pyriteous nodule; ( $f$ ) BSE image of the organic matter-rich layer crosscut by cracks filled by pyrite and marcasite; (g) detail of organic matter structures underlined by pyrite deposition. The white micro-zone consists of galena; (h) late filling of calcite and celestite. 

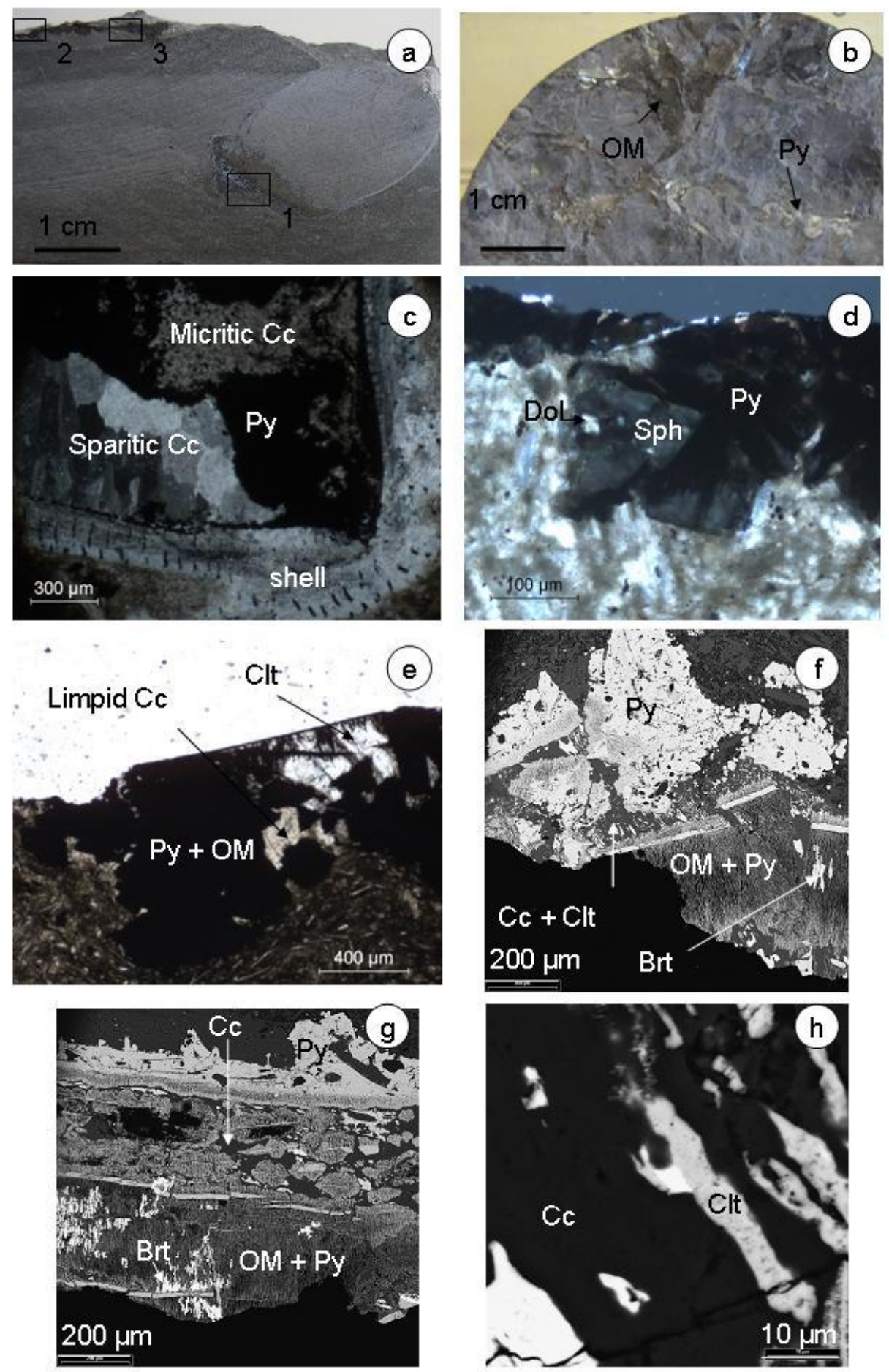

Fig. 5. Pyriteous structures associated with brachiopods (sample EST12436) - (a) macroscopic perpendicular view of a pyrite layer and a longitudinal cross-section of brachiopod shell; (b) macroscopic top view of broken pyrite layer; (c) microscopic view of longitudinal cross-section of brachiopod showing the pyrite and calcite filling (polarized light); (d) sphalerite encapsulating euhedral dolomite associated with pyrite layer (polarized light); (e) celestite and limpid calcite associated with pyrite - organic matter layer (polarized light); (f) BSE image of calcite and celestite crosscutting broken pyrite layer; (g) BSE image of complex organic structures associated with pyrite, barite and calcite; (h) BSE image of $\mathrm{Ba}-\mathrm{Sr}$ zoned celestite, white zones are Ba-rich. 

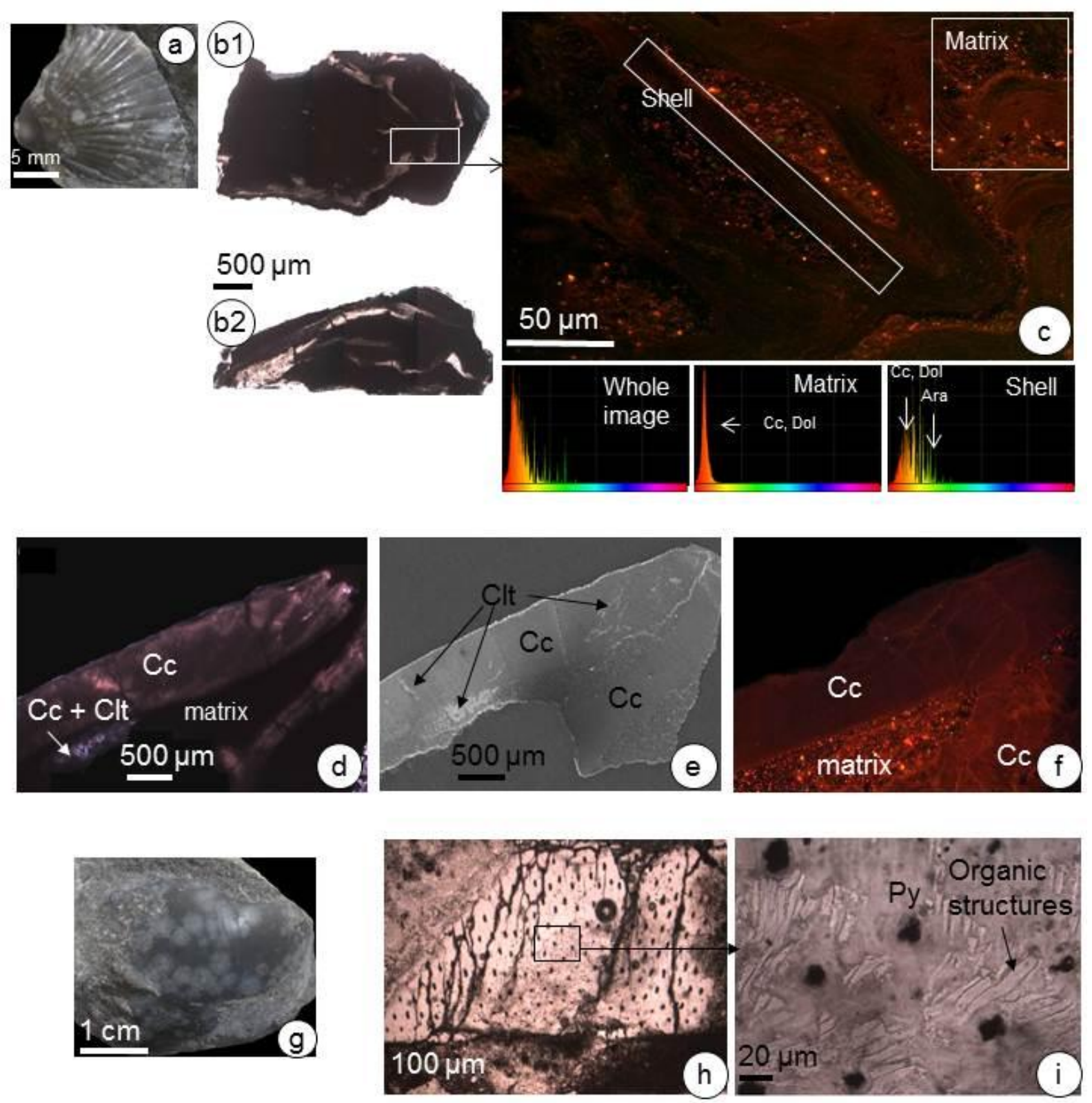

Fig. 6. Observation of entire shells in sample Bure 8 from the gallery.

Rhynchonella - (a) overview of the shell; (b1) cross-section parallel to the shell (transmitted natural light); (b2) cross-section perpendicular to the shell (transmitted natural light); (c) detail of a shell section observed in cathodoluminescence providing evidence of relictual bioaragonite (Ara).

Bivalve - (d) perpendicular section of the shell without visible micro-structures (transmitted polarized light); (e) secondary electron image of the perpendicular section providing evidence of celestite inclusions in recrystallized shell; (f) same perpendicular section observed in cathodoluminescence indicating calcite composition of the shell.

Terebratula - (g) overview of the shell; (h) sub-parallel cross-section of the shell providing evidence of numerous tubular structures filled by diagenetic pyrite (black points) (transmitted natural light); (i) detail of the shell showing tubular structures filled by pyrite and wellpreserved organic micro-structures (transmitted natural light). 

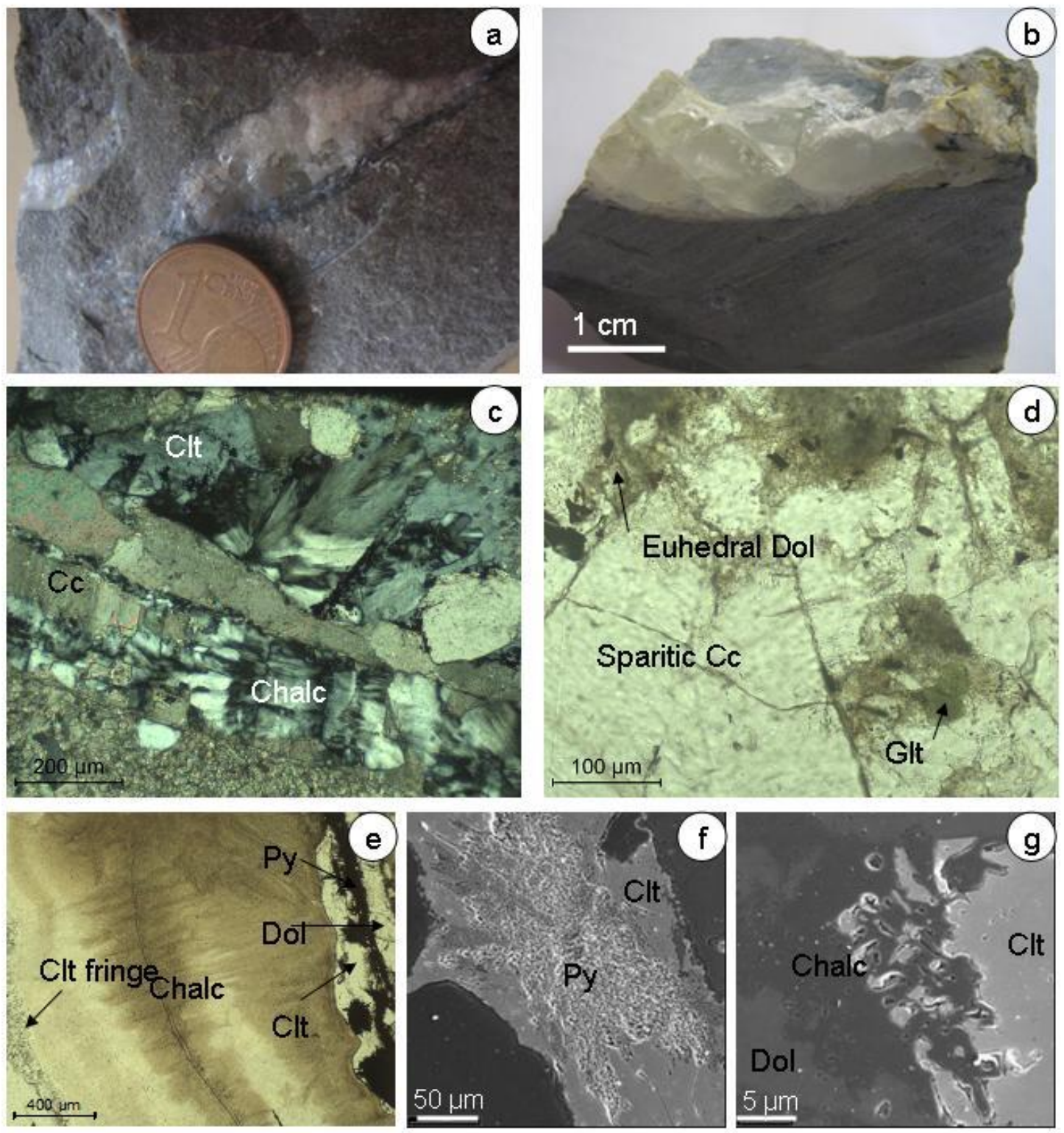

Fig. 7. Limestone sample Bure 3 from the gallery - (a) Replacement and infilling of shells by chalcedony; (b) Infilling of shell by cm-sized euhedral crystals of celestite; (c) microscopic view of the shell replacement by calcite and chalcedony (polarized transmitted light); (d) limpid euhedral grains of calcite encapsulating euhedral dolomite and glauconite (natural transmitted light); (e) infilling of shell by celestite and chalcedony (natural transmitted light); (f) contact between celestite and pyrite (BSE image); (g) irregular contact between chalcedony and celestite and dolomite suggesting disequilibrium (BSE image). 

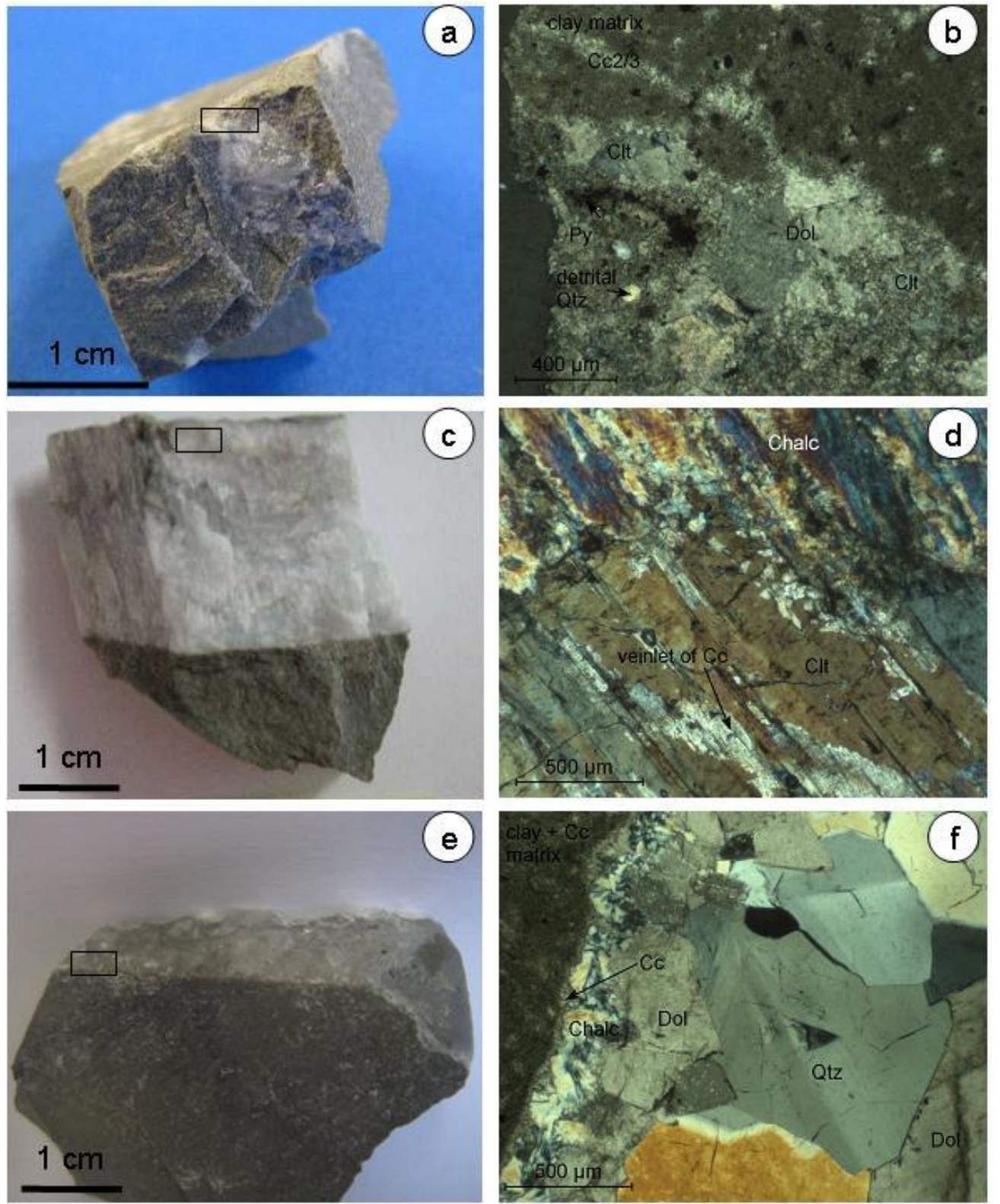

Fig. 8. (a) Celestite-dolomite crack in limestone (sample EST5485); (b) Late veinlet infilled with dolomite and minor celestite crosscut by chalcedony (sample EST5485, transmitted light); (c) Celestite crack in carbonate-rich claystone (sample EST20714); (d) Chalcedony followed by calcite veinlets crosscutting celestite crack (sample EST20714, polarized transmitted light); (e) Calcite-quartz crack in limestone (sample EST20433); (f) Crack rimmed by calcite and filled by euhedral quartz; a chalcedony veinlet crosscut the calcite rim (sample EST20433, polarized transmitted light). 

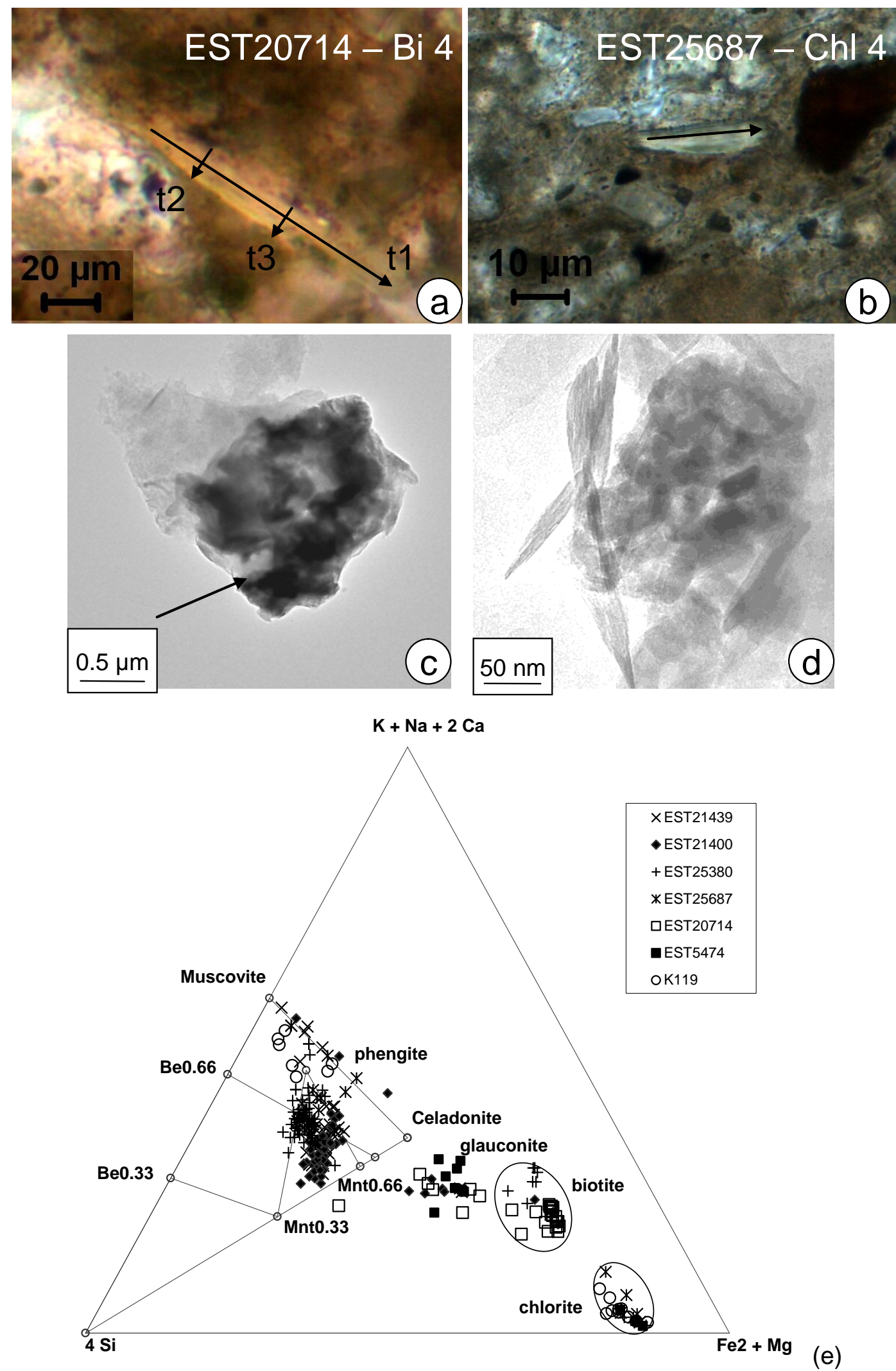

Fig. 9. (a) Micrograph of biotite in the sample EST20714 (Natural transmitted light); (b) micrograph of chlorite in sample EST25687 (Natural transmitted light); (c) and (d) Transmitted electron microscope photos of biotite particles showing their variable size, their irregular rims and the presence of dark rutile grains between the layers; (e) Triangular diagram $\mathrm{Si} / 4-(\mathrm{Na}+\mathrm{K}+2 \mathrm{Ca})-(\mathrm{Fe}+\mathrm{Mg})$ in which EPMA analyses of clay minerals, biotite $(\mathrm{Bi})$, chlorite (Chl) and muscovite (Mus) are plotted. 

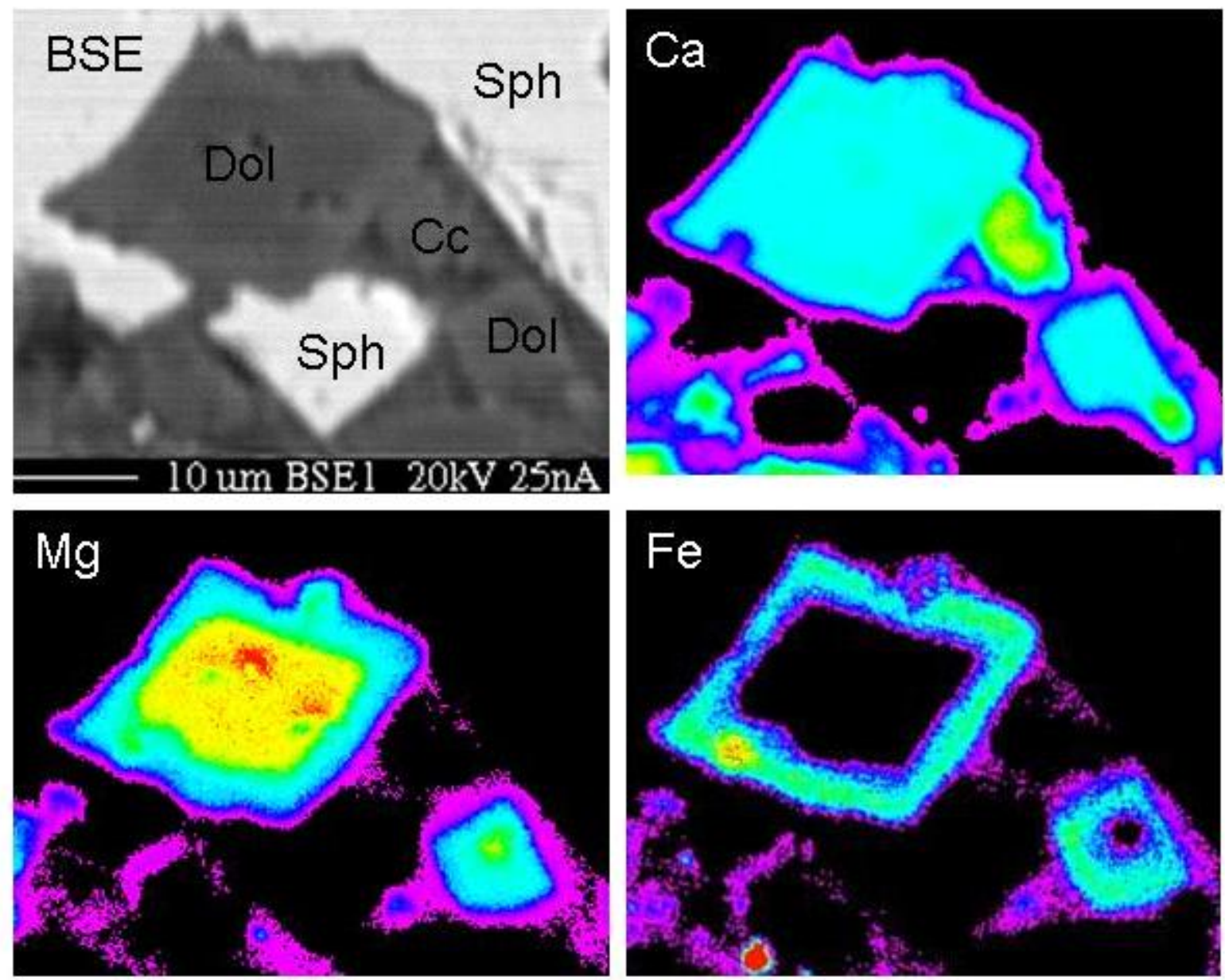

Fig. 10. BSE image of a euhedral dolomite grain encapsulated in sphalerite and EPMA Ca, $\mathrm{Mg}$ and Fe elemental mapping providing evidence of iron-rich rim. 


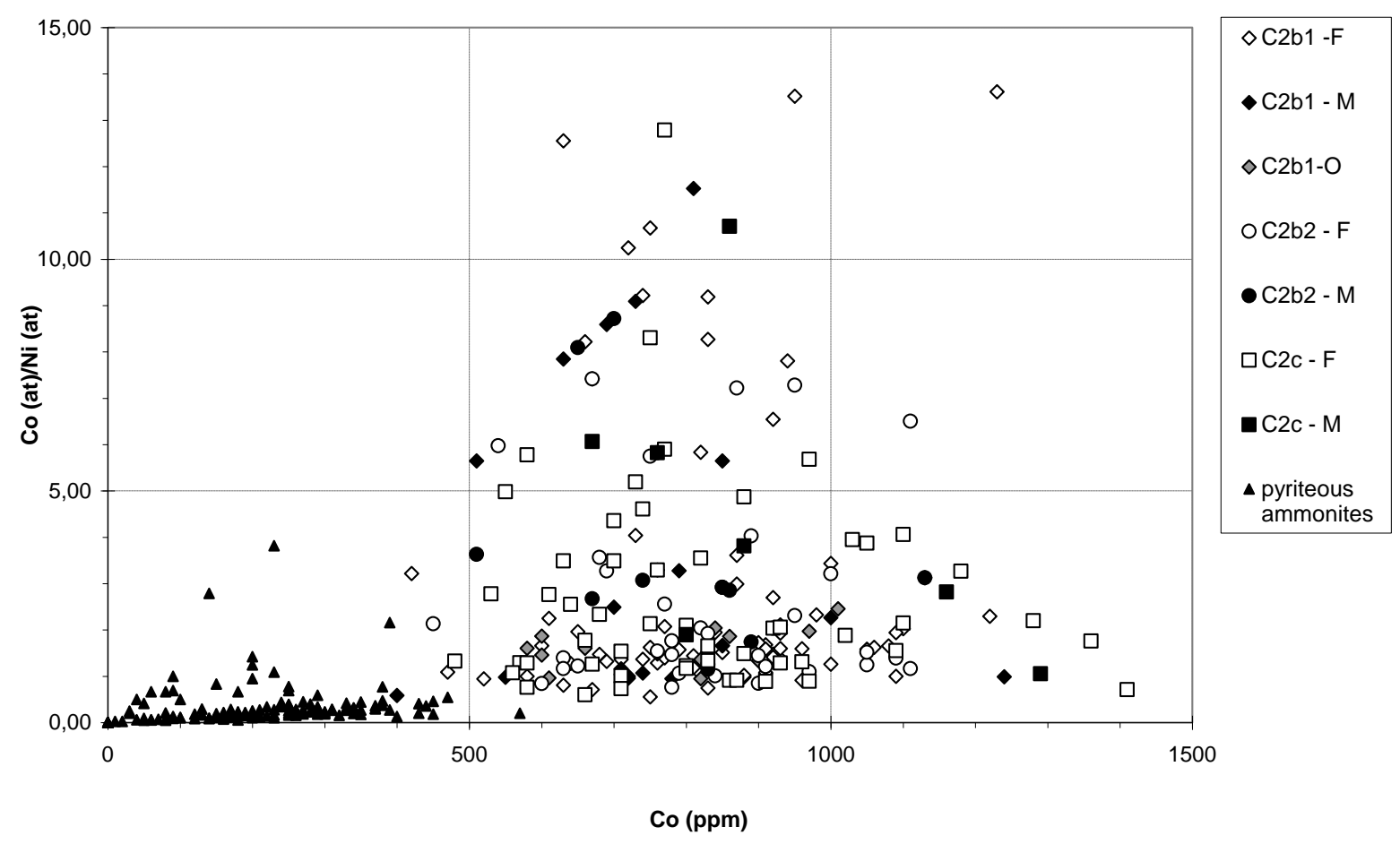

Fig. 11. Binary diagram of $\mathrm{Co} / \mathrm{Ni}$ ratio (atom ratio) in function of Co content (in ppm) in which the different types pyrite disseminated in the matrix, and on pyriteous nodules and ammonites of claystones from the COx unit.

Abbreviations: Isolated framboids of pyrite $(F)$, small clusters of framboids $(M)$, and framboids associated with organic structures filling fossils $(O)$. 
$\delta^{34} \mathrm{~S} \%$ (CDT)

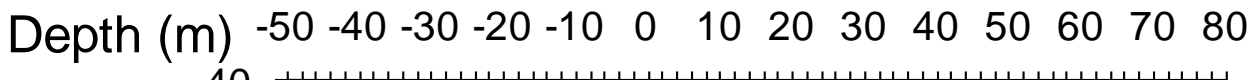
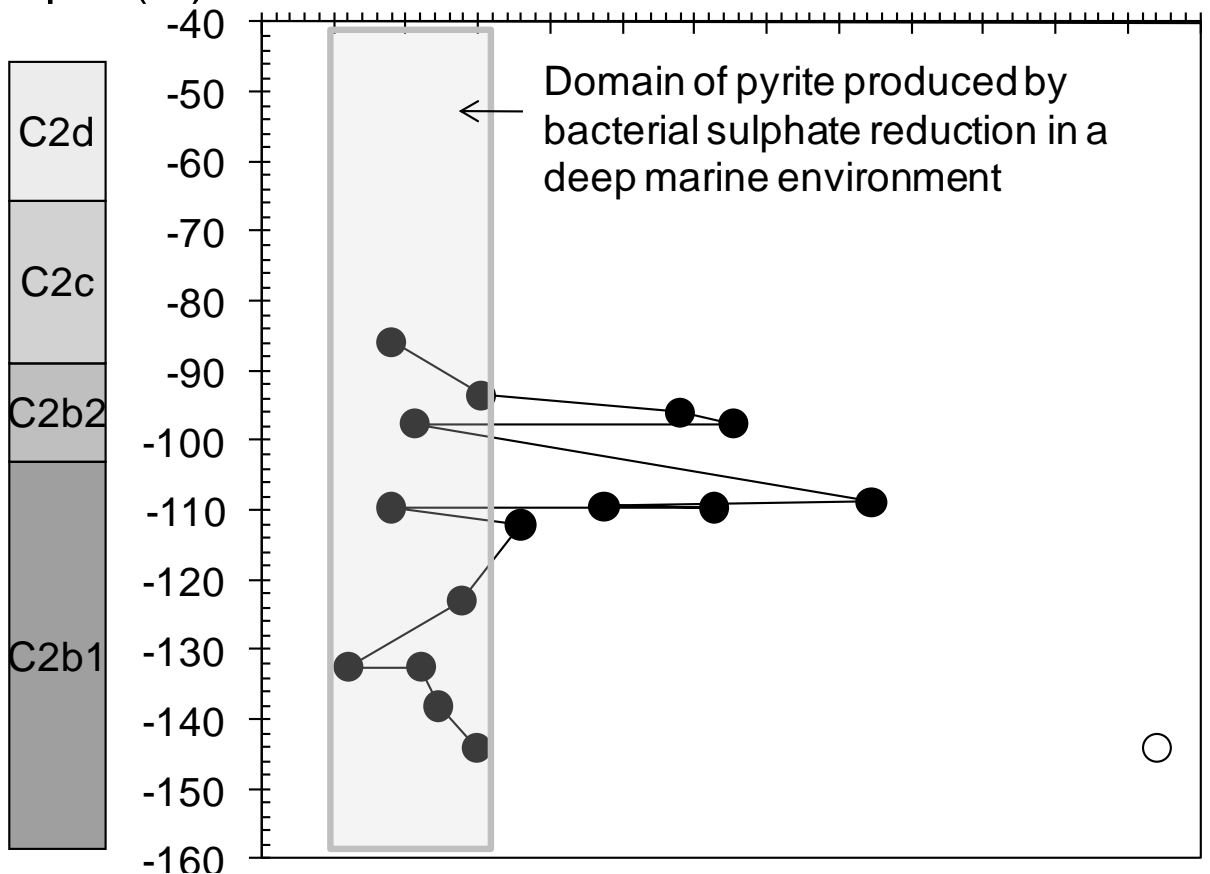

Fig. 12. Evolution of $\delta^{34} S$ of disseminated pyrite in bioturbation (black points) and of late pyrite mm-thick level (white point) as a function of depth. 


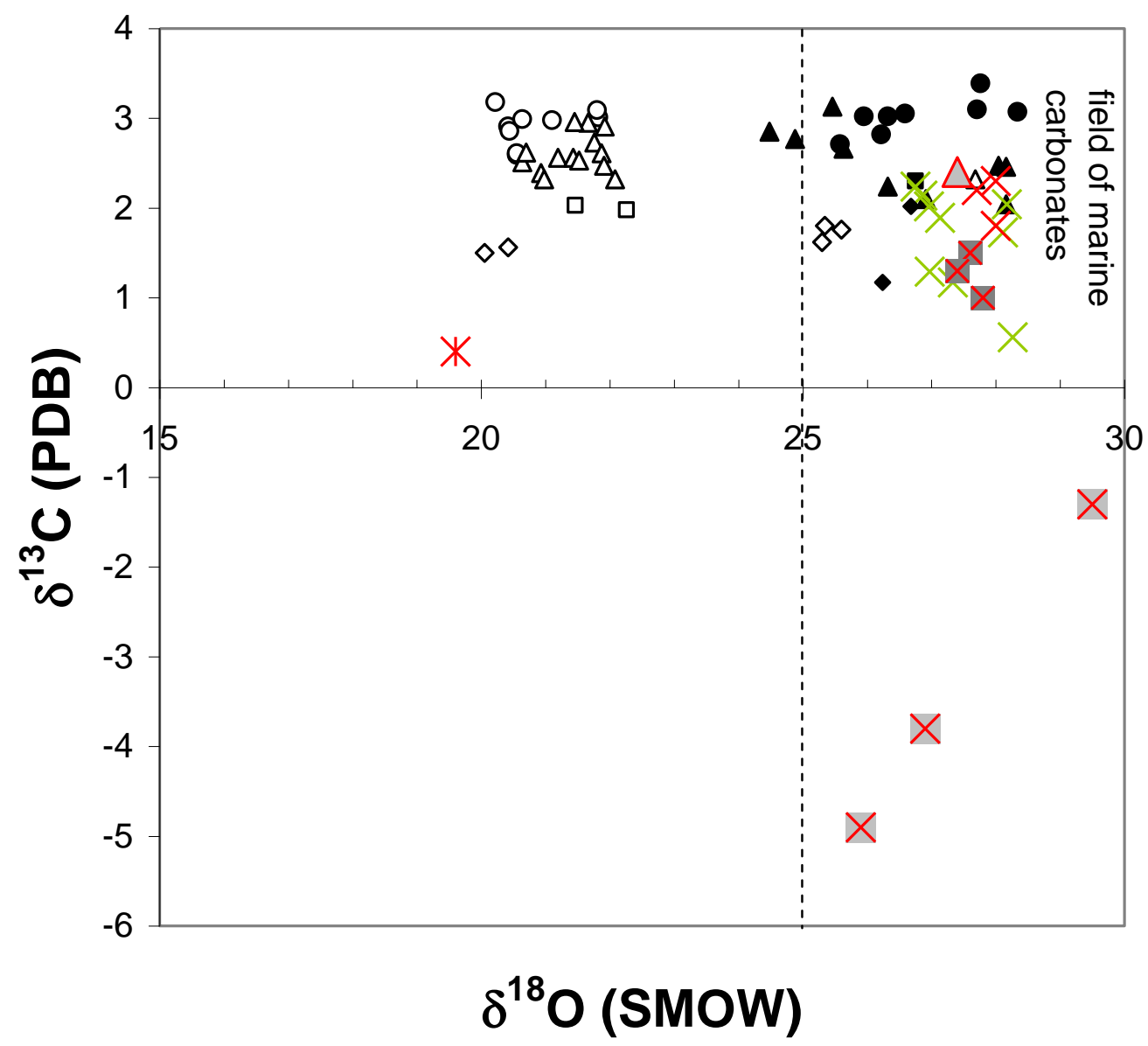

\begin{tabular}{|llll|}
\hline - Cc bulk LK & $\bullet$ Cc bulk Up Ox $\Delta$ Cc bulk Mi Ox $\times$ Cc bulk COX \\
- Cc bulk Bath & $\square$ Cc vug LK & o Cc vug Up Ox $\Delta$ Cc vug Mi Ox \\
$\diamond$ Cc vug Bath & $\times$ bulk COX & $\triangle$ Dol Mi Ox & $\quad$ Dol COX \\
$\times$ Sid COX & *late Cc & & \\
\hline
\end{tabular}

Fig. 13. Isotopic compositions of diagenetic carbonates of the clay formation (red symbols this study) reported in a $\delta^{13} \mathrm{C}-\delta^{18} \mathrm{O}$ diagram. Data of previous work of Buschaert et al (2004) concerning carbonates of the clay formation and adjacent carbonate platforms (black and white symbols).

Abbreviations: Cc, calcite; Dol, dolomite; Sid, siderite; LK, Lower Kimmeridgien limestones; Up Ox, Upper Oxfordian limestones; Mi Ox, Middle Oxfordian limestones; COx, CallovianOxfordian clay formation; Bath, Bathonian limestones. Bulk refers to the whole carbonate matrix in limestones and clay rocks, while vug refers to late diagenetic infillings. 


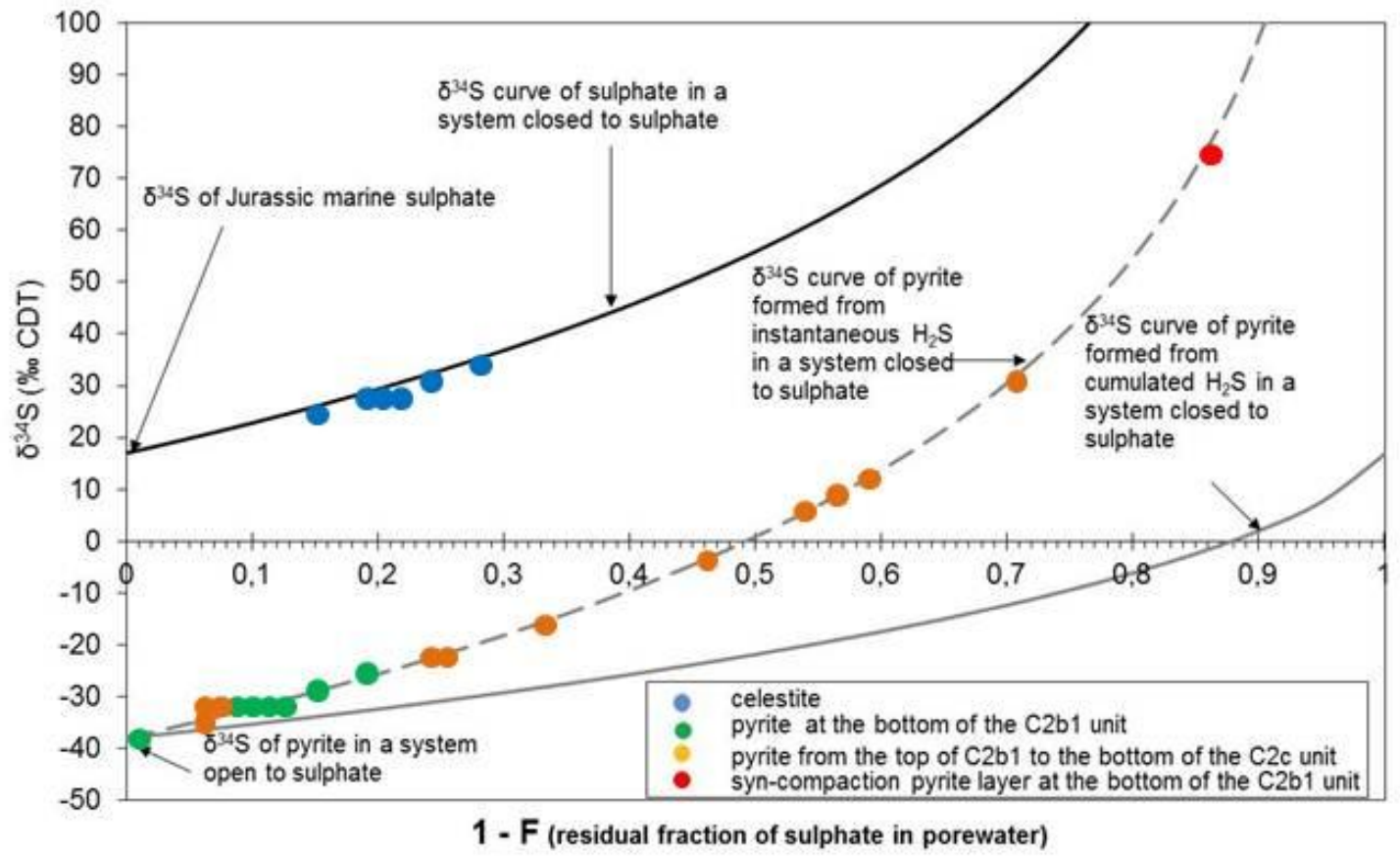

Fig. 14. $\delta^{34} \mathrm{~S}$ Curves of pyrite/ $\mathrm{H}_{2} \mathrm{~S}$ and sulphate resulting of a bacterial reduction of sulphate, in function of residual sulphate fraction $(F)$. 


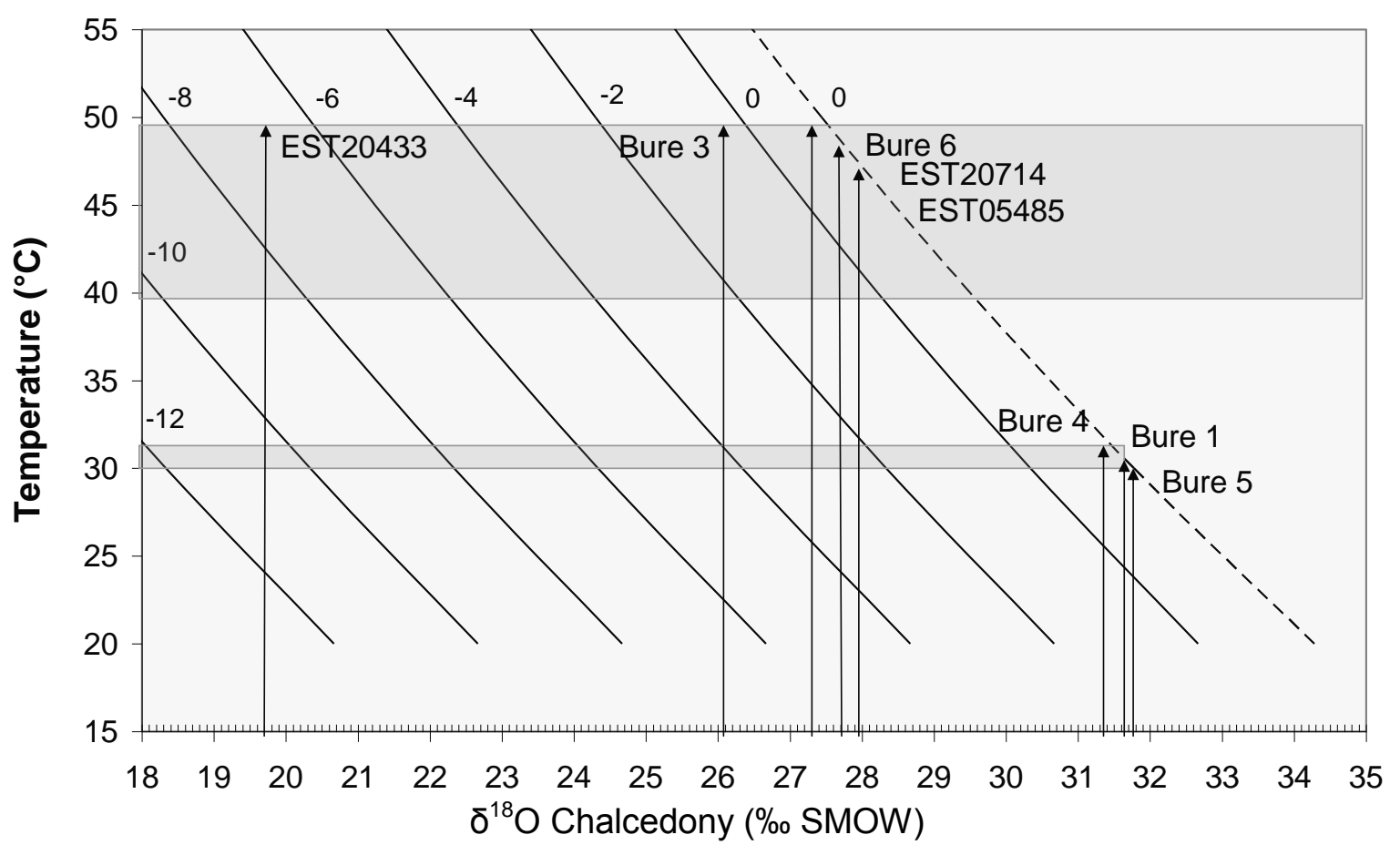

Fig. 15. $\mathrm{T}-\delta^{18} \mathrm{O}_{\text {silica }}$ diagram in which are reported curves of temperatures in function of silica $\delta^{18} \mathrm{O}$ calculated at equilibrium with fluids whose $\delta^{18} \mathrm{O}$ are $0,-2,-4,-6,-8,-10,-12 \%$ (SMOW). Grey areas correspond to temperature ranges of chalcedony formation in the Callovian-Oxfordian formation. Low temperatures around $30^{\circ} \mathrm{C}$ may correspond to beginning of burial, whereas $40-50^{\circ} \mathrm{C}$ range corresponds to the maximal burial of the clay formation. 


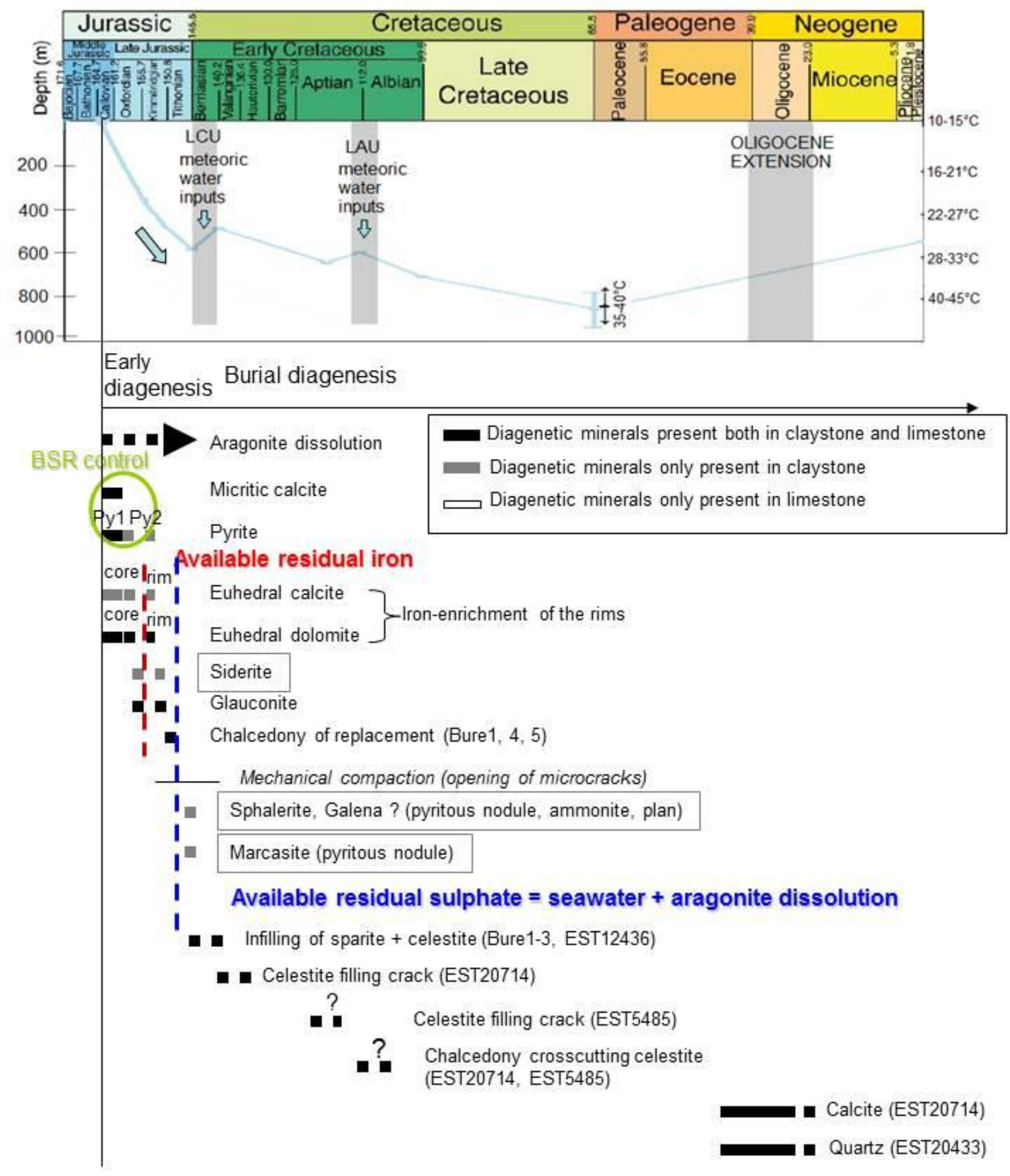

Fig. 16. Synthetic diagenetic sequence in the COx unit considering mineral formation processes, fluid origins and assumptions of absolute timing using the burial curve of Callovian sediments in the studied area for the EST210 borehole (URL) until the Kimmeridgian (modified from Brigaud et al., 2010, after the data of Vincent et al., 2007, Thierry et al., 1980 and Magniez et al., 1980). 


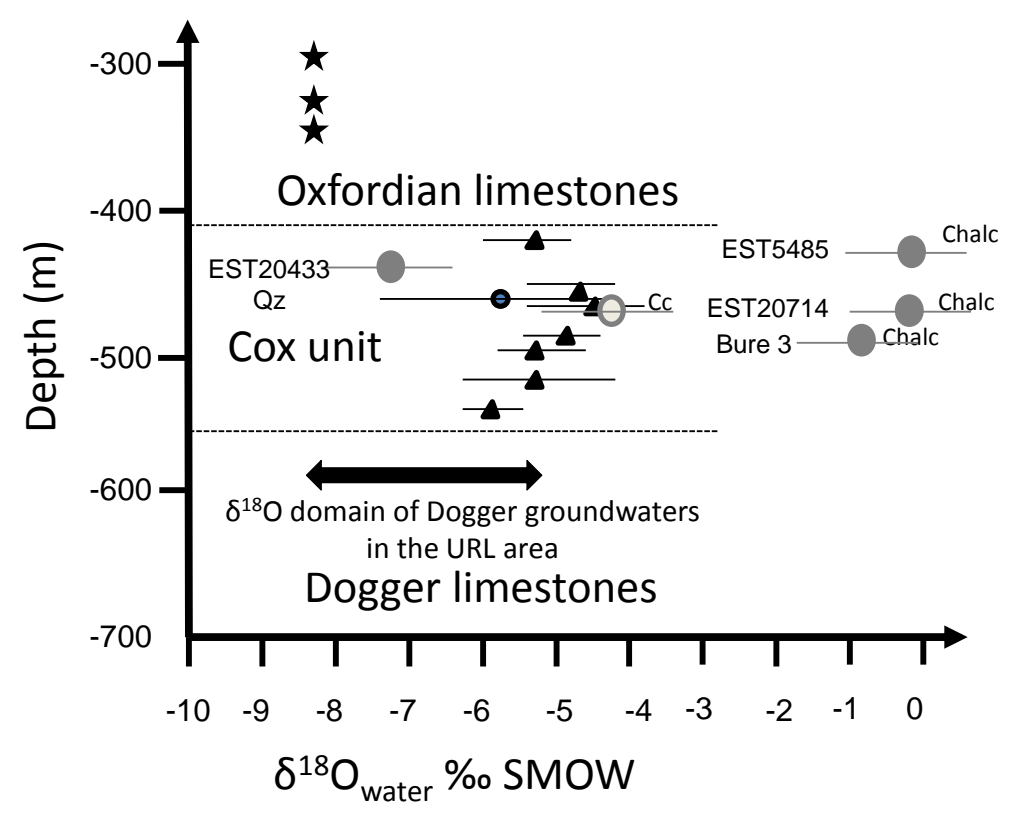

Fig. 17. $\delta^{18} \mathrm{O}$ of fluids at equilibrium with chalcedony and late diagenetic quartz and calcite reported in a $\delta^{18} \mathrm{O}$ profile of porewaters in the Cox unit. $\delta^{18} \mathrm{O}$ of groundwaters in adjacent limestones are also reported (after Giannesini, 2006). 